\title{
1 Integrating distribution models and habitat classification maps into Marine 2 Protected Area planning
}

3 Renata Ferrari ${ }^{1,2}$, Hamish Malcolm ${ }^{3}$, Joe Neilson ${ }^{5}$, Vanessa Lucieer ${ }^{4}$, Alan Jordan ${ }^{6}$, Tim

4 Ingleton $^{7}$, Will Figuera ${ }^{1}$, Nicola Johnstone ${ }^{8}$, Nicole Hill ${ }^{4}$

$5 \quad{ }^{1}$ University of Sydney, School of Life and Environmental Sciences, Edgeworth David Bld, Science Road,

$6 \quad$ NSW 2006, Australia. Renata.ferrari@sydney.edu.au will.figueira@sydney.edu.au

$7 \quad{ }^{2}$ Australian Institute of Marine Sciences, PMB No. 3, Townsville, Queensland 4810, Australia

$8{ }^{3}$ Fisheries Research, NSW Department of Primary Industries, 32 Marina Drive Coffs Harbour NSW 2450,

9 Australia.Hamish.malcolm@dpi.nsw.gov.au

$10{ }^{4}$ Institute for Marine and Antarctic Studies, University of Tasmania, Private Bag 129, Hobart, TAS 7001,

11 Australia. Nicole.hill@utas.edu.au vanessa.lucieer@utas.edu.au

$12{ }^{5}$ Marine Planning, NSW Department of Primary Industries, 84 Crown St, Wollongong, NSW 2520,

13 Australia. joe.neilson@ dpi.nsw.gov.au

$14{ }^{6}$ Fisheries Research, NSW Department of Primary Industries, Port Stephen Fisheries Institute, Locked Bag

15 1, Nelson Bay, NSW 2315, Australia. alan.jordan@dpi.nsw.gov.au

$16 \quad{ }^{7}$ NSW Office of Environment and Heritage, 59-61 Goulburn St, Sydney, NSW 2000, Australia.

17 Tim.Ingleton@environment.nsw.gov.au

$18{ }^{8}$ Marine Strategy, NSW Department of Primary Industries, 32 Marina Drive Coffs Harbour NSW 2450,

19 Australia. nicola.johnstone@ dpi.nsw.gov.au

Short running title: Maps and models for conservation planning

Keywords: ecological and functional surrogates, endemic and threatened species, fish, habitat classification scheme, habitat maps, stakeholders, local knowledge and expertise, marine protected areas, Marxan, conservation prioritization, spatial management, conservation planning, data-deficient ecosystems.

Type of article: Letter

Corresponding author: Australian Institute of Marine Sciences, PMB No. 3, Townsville, Queensland 4810, Australia. Mobile: +(61) 425676050 R.Ferrari@aims.gov.au_or renata.ferraril@gmail.com 


\section{Abstract}

39 Effective conservation planning requires biotic data across an entire region. In

40 data-poor ecosystems conservation planning is informed by using environmental

41 surrogates (e.g. temperature) predominantly in two ways: to develop habitat classification

42 schemes (1) or develop species distribution models (2). We test the utility of both

43 approaches for conservation planning of marine ecosystems, and rank environmental

44 surrogates, such as depth and distance from shore, according to their power to predict the

45 distribution and abundance of biotic species. Specifically, we compared a habitat

46 classification scheme; based on coarse levels of habitat types derived from depth and

47 distance from shore; against species distribution models, which predict fish abundance

48 and prevalence as a function of environmental surrogates (depth, distance from shore,

49 latitude, reef area, zoning, and several metrics of habitat structural complexity). We

50 consistently set conservation target levels to $21 \%$ of each conservation feature, following

51 global standards and a sensitivity analyses. Thus when running scenarios to protect fish

52 species we aimed to protect at least $21 \%$ of each species, and when running scenarios of

53 habitat classes, we aimed to protect at least $21 \%$ of each habitat class. We found that

54 when aiming to protect $21 \%$ of the chosen conservation targets, distribution models

55 protected $21 \%$ of the predicted abundance/occurrence of all modelled species and

56 functional groups, but did not protect most habitats. Contrastingly, using a habitat

57 classification scheme protected $21 \%$ of all habitat types and $34 \%$ of all species and

58 functional groups, but required protecting three times more area. Thus, using only

59 distribution models as targets in data-poor ecosystems could be a risky conservation

60 planning strategy. Ultimately the best conservation outcomes were achieved by

61 incorporating local knowledge to synthesize the conservation outcomes of both scenarios. 


\section{Introduction}

63 Systematic conservation planning approaches, such as Marxan (Watts and

64 Possingham 2013), have been used extensively as a decision support tool for spatial

65 planning over the past 30 years to improve conservation benefits and outcomes (see full

66 explanation of systematic conservation aproaches in Margules \& Pressey 2000; Pressey

67 \& Cowling 2001) and inform adaptive management (McCook et al. 2010; Levin et al.

68 2013). Modern conservation planning uses systematic approaches to increase the

69 probability of achieving conservation objectives; which improve integration of biotic,

70 social and environmental data (Groves and Game 2016), especially compared to ad-hoc

71 or even "expert" selection approaches (Cowling et al. 2003; Stewart, Noyce \&

72 Possingham 2003; Leslie 2005). Spatial systematic conservation planning approaches

73 objectively select areas most likely to maximise representation of conservation features

74 (e.g. biodiversity), avoiding biases where datasets and areas are large (Margules \&

75 Pressey 2000; Ferrier 2002; Sarker et al. 2006). Additionally, systematic conservation

76 planning can be used to maximise conservation benefits whist reducing socioeconomic

77 opportunity costs, such as restricting areas from fisheries (Klein et al. 2008a; Klein et al. 78 2008b).

79 Although lagging behind terrestrial conservation efforts, systematic conservation

80 planning approaches have increasingly been used in planning Marine Protected Areas

81 (MPAs) over the past 15 years (Leslie et al. 2003; Fernandes et al. 2005; Cook \& Auster

82 2006; Klein et al. 2015). However, there are strong constraints (e.g. restricted time

83 underwater, difficulty for remote sensing methods to penetrate the water surface, depth

84 limits in SCUBA diving restrict most studies to shallow reefs)_associated with obtaining

85 biological information at scales suitable for undertaking systematic planning in the 
86 marine environment (Stevens \& Connolly 2004). Systematic planning is most effective

87 when data are available across the entire planning area, which often does not exist in

88 marine ecosystems (Ban 2009; Elith and Leathwick 2009). This can constrain effective

89 systematic conservation planning due to missing data within the majority of the planning

90 area. For instance, where there are few spatial data points, an algorithm will select those

91 planning units where data is available, potentially misrepresenting planning units without

92 data. Where biotic data are sparsely available their spatial distributions can be inferred by

93 establishing their relationship with environmental data (Stevens and Connolly 2004;

94 Johnston et al. 2015). This includes the use of habitat classification schemes where

95 environmental surrogates, such as temperature or depth, represent biotic patterns (Sarker

96 et al. 2005; Moore, Van Niel \& Harvey 2011) and modelling approaches that enable

97 spatial predictions of individual species distributions based on their relationships with

98 environmental variables (Guisan et al. 2013).

99 The differential effort required to develop robust classification schemes and

100 distribution models has led to many studies comparing these approaches for systematic

101 conservation planning. In terrestrial ecosystems, distribution models can improve

102 conservation planning outcomes compared to classification schemes (Guisan et al. 2013).

103 Yet, developing robust distribution models that are adequate for conservation planning

104 requires statistical expertise that may not always be accessible to managers (Elith and

105 Graham 2009). Designing classification schemes that represent biotic distributions is

106 more feasible because certain environmental surrogates, such as depth, are strongly

107 related to biotic communities (Malcolm et al. 2011). Evidence supporting the use of

108 distribution models in marine conservation planning is lacking (Ballantine and Langlois 
109 2008; Klein et al. 2015) and classification schemes have been more readily applied

110 (Barrett et al. 2003; Jordan et al. 2005; Malcolm et al. 2011). Consequently, there are

111 limited guidelines for integrating the results of multiple conservation scenarios that use

112 distribution models and classification schemes in marine ecosystems (Ballantine and

113 Langlois 2008).

114 This study tested the benefit of using distribution models against using habitat

115 classification schemes to inform conservation planning of marine ecosystems. We used

116 an MPAs in south-eastern Australia, the Solitary Islands Marine Park (SIMP), as a case

117 study to advance marine systematic conservation planning in three ways. Firstly, we

118 ranked environmental variables according to how strong they relate to the biological data

119 of conservation interest, also referred to as predictive power. This allows for the

120 prioritization of data collection, which is essential to managers with limited resources.

121 Secondly, we quantitatively compared conservation trade-offs between conservation

122 planning scenarios using classification schemes and distribution models, for instance we

123 compared the output of scenarios that use a habitat classification scheme as a

124 conservation feature against scenarios that use the predicted species distribution models

125 as a conservation feature. Thirdly, we developed a decision framework to incorporate

126 local knowledge with the results of conservation scenarios using classification schemes

127 and distribution models.

\section{Methods}

129 Study site

130 The study was conducted in the SIMP on the east Australian coast. The SIMP was

131 established in 1991 as a multiple use MPAs that contains 'no take' zones (Sanctuary 
132 Zones: SZ) and zones where fishing is permitted. It has undergone adaptive management

133 twice through rezoning, with the representation of biodiversity a key objective for

134 rezoning. The subtropical MPAs has high biological diversity due to being in a tropical-

135 temperate transition with extensive reef habitats (Harriott, Smith \& Harrison 1994;

136 Malcolm, Jordan \& Smith 2010).

137 The SIMP covers $720 \mathrm{~km}^{2}$ of coastal waters, in this study the SIMP was separated

138 into northern $\left(132.5 \mathrm{~km}^{2}\right)$ and southern $\left(85.01 \mathrm{~km}^{2}\right)$ regions to reflect the coverage of

139 high-resolution seabed mapping conducted in the area (Fig. 1) (Jordan et al. 2010;

140 Malcolm et al. 2010).

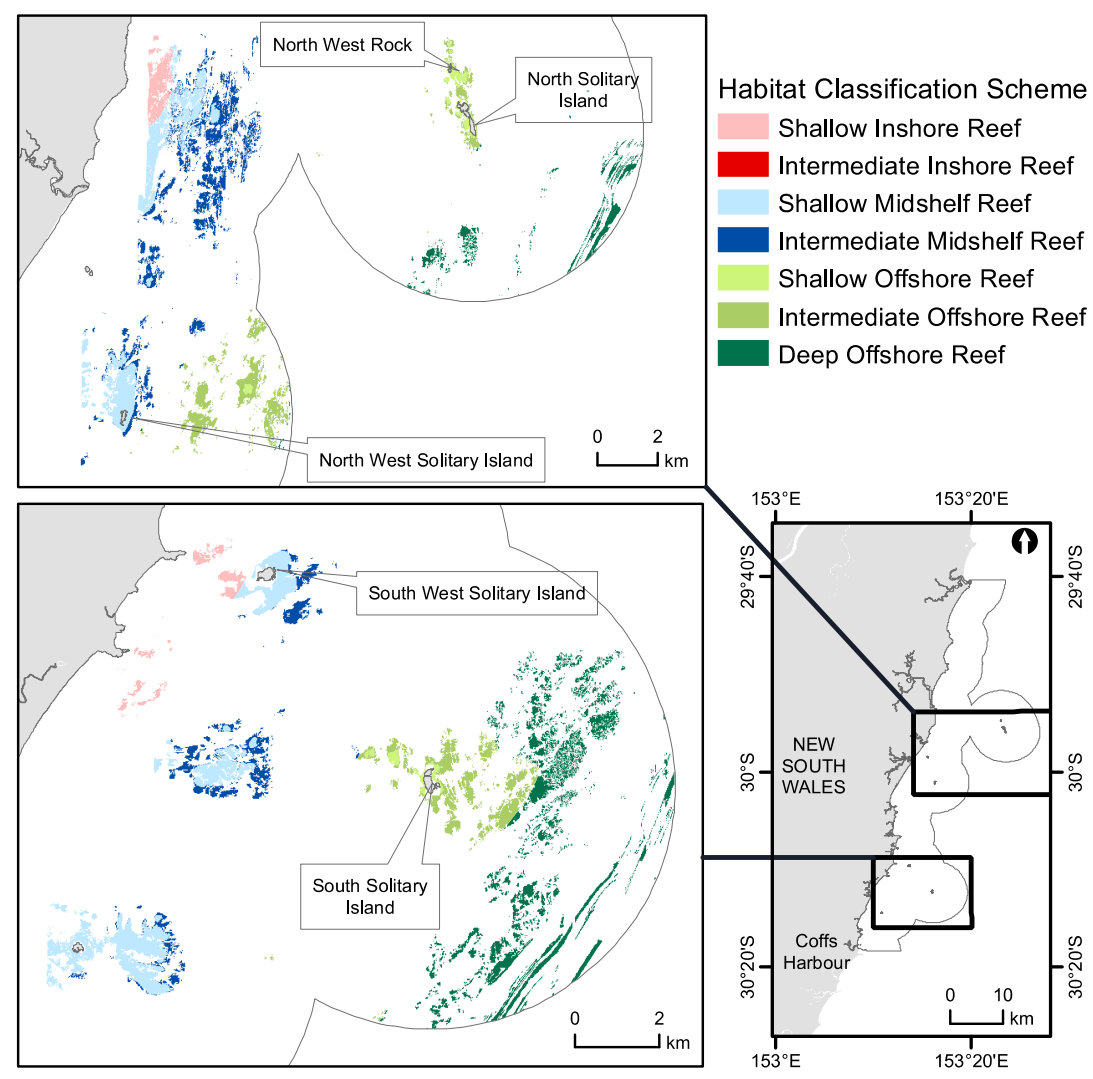

141

142 Figure 1 Map of the study area with the Habitat Classification Scheme (HCS)

143 highlighted in colour. The grey line denotes the marine park boundary. Islands were

144 clipped-out for the Marxan analyses. 


\section{Sampling methods}

\section{Field methods and video processing of fish data}

147 Fish were surveyed on reefs using Baited Remote Underwater Video (BRUV),

148 with 56 deployments at 19 sites in the northern region and 103 deployments at 34 sites in

149 the south (totalling 159 thirty-minute BRUV deployments). Each BRUV unit consisted of

150 a digital video camera with wide-angle lens in an underwater housing, an attachment

151 frame, a bait-pole with bait, and a rope and float system linking the BRUV to the surface

152 (Malcolm, Jordan \& Smith 2011). Baits were used to attract fish to a viewing area in

153 front of the camera with $1 \mathrm{~kg}$ of mashed pilchard Sardinops neopilchardus, attached to

154 the end of a bait-pole at a distance of $1.5 \mathrm{~m}$ from the lens (Hardinge et al. 2013).

155 Data were analysed post-survey using EventMeasure-stereo software (SeaGIS Pty.

156 Ltd.) with the identity of each fish species and an index of its relative abundance (MaxN)

157 recorded from each replicate. MaxN was the maximum number of individual fish of each

158 species in the frame at any one time during the 30-min record. This eliminated the chance

159 of recounting individual fish. The field-of-view was standardized to a distance of

160 approximately $3 \mathrm{~m}$ behind the bait to minimize the effects of water visibility on the

161 measure of relative abundance, further details of sampling methodology can be found in

162 Cappo et al. (2003) and Harasti et al. (2015).

163 A restricted number of targeted fish were selected (Table 1) using a combination

164 of species lists from recreational fishing competitions in SIMP (Henry, Matthews \&

165 Kelly 1996), commercial fishing data for NSW (Rowling, Hegarty \& Ives 2010), and

166 BRUV surveys undertaken extensively throughout the SIMP (Malcolm, Jordan \& Smith

167 2011). Additionally five fish functional groups were selected to run SDMs, these groups 
168 included fish from the entire assemblage (Table 1). The first two groups were trophic

169 functional groups of high commercial value. The third group was particularly vulnerable

170 to fishing impacts, the fourth group included species with high-conservation value in

171 relation to global representation within this subtropical marine park, and the fifth group,

172 wrasse family (Labridae), was included as a surrogate for overall fish diversity. The

173 Labridae account for $~ 17 \%$ of the reef fish species recorded from the SIMP (Malcolm,

174 Jordan \& Smith 2010) and is an effective surrogate to represent reef-fish diversity in the

175 SIMP (Malcolm \& Smith 2010).

177 Table 1 Eight fish species and five functional groups of commercial and/or conservation 178 importance selected in this study for SDMs. Details of species placement in functional 179 groups in Table S1.

\begin{tabular}{lll}
\hline Species & Common Name & Rationale \\
Chrisophrys auratus & Snapper & Key target fished species \\
Nemadactylus douglasi & Grey morwong & Key target fished species \\
Notolabrus gymnogenis & Crimson banded wrasse & Key target fished species \\
Opthalmolepis lienolatus & Maori wrasse & Key target fished species \\
Rhabdosargus sarba & Tarwhine & Key target fished species \\
Glaucosoma scapulare & Pearl perch & Key target fished species \\
Choerodon venustus & Venus tusk fish & Key target fished species \\
Brachaelurus waddi & Blind shark & By catch species \& \\
& & subtropical endemic \\
\hline Functional Group* & & Rationale \\
Target predator fish & & Targeted trophic group \\
Target piscivore fish & & Targeted trophic group \\
Benthic sharks & & Vulnerable group \\
Subtropical endemics & & High conservation value \\
Labrids & & Surrogate group \\
\hline *See Supplementary Information for species lists per group &
\end{tabular}

181 
Subtidal reefs were digitised from swath-acoustic data and spatial variables were

184 calculated for the reef areas in both northern and southern regions: latitude, distance from

185 mainland, management zone ('no-take' vs fished), reef area, depth, standard deviation of

186 depth, curvature, slope, fractal dimensions and surface rugosity (Table 2).

187 Swath acoustic mapping was conducted over the two survey areas using a 125

$188 \mathrm{kHz}$ GeoSwath interferometric sidescan sonar (Jordan et al. 2010). Bathymetric and

189 seabed reflectance (backscatter) data were gridded at $5 \times 5 \mathrm{~m}$ grid cell resolution and the

190 spatial layers were created in ArcMap10 (ESRI, USA). Areas of rocky reef were digitised

191 by hand at a constant scale of 1:2000 using a combination of the bathymetry and

192 backscatter. Overall, rocky reef areas were generally characterised by regions of relief,

193 relatively higher backscatter reflectance and grey scale heterogeneity (texture). In

194 contrast, unconsolidated substratum were characterised by regions of relatively little

195 relief, homogeneous textural complexity and weaker seafloor reflectance (see Jordan et

196 al., 2010, for details). Spatial variables (Table 2) were then calculated on a 5 x 5 cell

197 basis for the $5 \times 5 \mathrm{~m}$ gridded data using Fledermaus (QPS, USA) and ArcMap10 (ESRI,

198 USA).

199 Habitat classification scheme (HCS)

200 The HCS used in our study was designed for the SIMP based on assemblage

201 patterns of fishes and prevalence patterns of major benthic habitat formers (Malcolm et al.

202 2011). The assemblage patterns of fishes are mostly reflected on depth and distance from

203 shore, thus HCS considers depth (shallow 0-25 m, intermediate 25-50 m, deep >50 m)

204 and distance from mainland (inshore 0-1.5 km, midshelf $1.5-6 \mathrm{~km}$, offshore $>6 \mathrm{~km}$ ); 
205 resulting in seven categories: shallow inshore; shallow midshelf, shallow offshore,

206 intermediate inshore, intermediate midshelf, intermediate offshore, deep offshore (Fig. 1)

207 (Malcolm et al. 2012). This reflects the presence of islands and adjacent reefs on the

208 midshelf and offshore waters.

209 Species distribution models (SDM)

210 The relationship between the prevalence/abundance of fish, for nine species and

211 five functional groups (Table 1), and the spatial variables (Table 2) and management

212 zone was assessed using generalized and generalized hierarchical models in R (R Core

213 Team, 2014). First, the spatial variables (Table 2) were explored followed by model

214 refining and assessment, third final models were used to predict fish distributions across

215 each of the studied regions, all models used empirical data.

216 Table 2 Spatial variables tested as potential predictors in the SDMs, those used in the

217 habitat classification scheme are marked with ${ }^{\wedge}{ }^{\wedge}$. Some of these variables were collinear

218 (i.e. surface rugosity and standard deviation of depth), in which case we used only one of

219 the variables in the SDMs. Variables not used in the SDMs are greyed out. Variables that

220 were $\log$ transformed in analyses are marked with an asterisk *.

\begin{tabular}{|c|c|}
\hline Variable & Description \\
\hline Depth & Mean depth at each cell in the $5 \mathrm{~m}$ grid (range $14.6-73.7 \mathrm{~m}$ ). \\
\hline Distance & $\begin{array}{l}\text { Distance from the } 5 \mathrm{~m} \text { grid cell where the BRUV were deployed to the } \\
\text { coastline }(\mathrm{km}) \text {. }\end{array}$ \\
\hline Zoning & Inside or outside no take zone, no fishing allowed. \\
\hline Latitude & Latitude \\
\hline Curvature & $\begin{array}{l}\text { The slope of each cell in the } 5 \mathrm{~m} \text { grid in relation to a } 3 \times 3 \text { cell } \\
\text { analysis. }\end{array}$ \\
\hline $\begin{array}{l}\text { Depth standard } \\
\text { deviation }\end{array}$ & $\begin{array}{l}\text { Standard deviation of depth, represents the dispersion of depth values } \\
\text { (in meters) around the mean depth within a square } 3 \times 3 \text { cell window. } \\
\text { In this analyses the cell values are } 5 \times 5 \text { m so the analysis window is } \\
15 \times 15 \mathrm{~m} \text {. }\end{array}$ \\
\hline $\begin{array}{l}\text { Fractal } \\
\text { dimension }\end{array}$ & $\begin{array}{l}\text { This is a measure of the } 2 \text { dimensional complexity of the shape of the } \\
\text { reef. Mean fractal dimension approaches one for shapes with simple }\end{array}$ \\
\hline
\end{tabular}




\begin{tabular}{|c|c|}
\hline & perimeters and approaches two when shapes are more complex. \\
\hline$*$ Reef area & Total area of reef in each planning unit $\left(\mathrm{m}^{2}\right)$. \\
\hline $\begin{array}{l}\text { Fractal } \\
\text { perimeter }\end{array}$ & The length of the perimeter of each reef fraction $(\mathrm{m})$. \\
\hline Surface rugosity & $\begin{array}{l}\text { Surface rugosity is a measure of the variation in three dimensional } \\
\text { orientation of grid cells within a } 3 \times 3 \text { cell neighbourhood. This } \\
\text { variable captures variability of aspect and slope in a single measure. } \\
\text { Rugosity values can range from } 0 \text { (no seafloor variation) to } 1 \\
\text { (complete seafloor variation). Typical values are between } 0 \text { and } 0.4 \text {. }\end{array}$ \\
\hline Slope & $\begin{array}{l}\text { Identifies the slope (gradient, or rate of maximum change in } \mathrm{z} \text { value) } \\
\text { from each cell of a raster surface. }\end{array}$ \\
\hline $\begin{array}{l}\wedge \text { Depth } \\
\text { categories }\end{array}$ & Depth of seabed from bathymetric charts $(0-25 \mathrm{~m}, 26-50 \mathrm{~m},>50 \mathrm{~m})$. \\
\hline $\begin{array}{l}\wedge \text { Distance } \\
\text { categories }\end{array}$ & $\begin{array}{l}\text { Distance from the shore measured perpendicularly from the coastline } \\
(\mathrm{km}) \text {. }\end{array}$ \\
\hline
\end{tabular}

223 where two variables were correlated at Pearson's $r>0.7$, the variable likely to be most

224 proximal in determining the distribution of fish was chosen (Table 2). The distribution of

225 variables was also checked and highly skewed variables were log transformed (Table 2).

226 As a preliminary step, Generalised Additive Models (GAM) of each predictor variable

227 against the prevalence of each species was used to assess the form of each response using

228 package $m g c v$ (Wood 2011). The following interactions were considered: depth *

229 standard deviation of depth, depth*fractal dimensions, and depth*latitude.

230 Not all functional groups or species were abundant enough to run abundance

231 models (see Supplementary Information Fig 5). Predictions from abundance models are

232 better than prevalence models as conservation feature layers in Marxan, because they

233 contain more information about how good the habitat is for supporting the species of

234 conservation interest. Thus, we used abundance models when possible and prevalence

235 models otherwise. We considered using prevalence models for all groups, but chose to 
236 use a combination of both given that: (1) abundance models allow the selection of areas

237 of high abundance to protect groups that are abundant enough, (2) prevalence models

238 allow the protection of rare places where non-abundant species occur, (3) many of the

239 species and groups for which we modelled prevalence were recorded in very low

240 abundances at individual sites (mostly less than 3), which in essence is not very different

241 to presence-absence.

242 The abundance (when possible) or prevalence of fish was modelled as a function

243 of the environmental variables and management zone using packages mass, stats and

244 Ime4 in R (Venables, 2002, Venables and Ripley 2002, R Core Team 2014, Bates et al.

245 2015). Predictor variables were scaled and centred for analysis. The choice of model was

246 informed by the potential need to account for (i) random effects of site, (ii) zero inflated

247 or over dispersed data (i.e. poisson, negative binomial or zero inflated glm), and (iii)

248 spatial autocorrelation. Model forward selection was based on Aikaike Information

249 Criteria (AIC) (Bolker et al. 2009) and final model adequacy was assessed using residual

250 plots (Bjornstad 2013). Assumptions of independence (to ensure no spatial

251 autocorrelation was present) were checked for all final models, by plotting the correlation

252 between model residuals to a distance of $4.5 \mathrm{~km}$ (the average inter reef distance) using

253 the spline.correlogram function in the package $n c f$ (Bjornstad, 2013) with 200 bootstrap

254 samples.

255 "Site" was tested as a random effect in the original models to account for potential 256 spatial autocorrelation. If no significant $(\mathrm{p}>0.05)$ improvement of model fitness resulted 257 from including "Site" as random effect and if no evidence of spatial autocorrelation was 258 found in residual correlograms of models without the random effect, "Site" was removed 
259 from the model following the parsimony principle (Bates, 2015). Fish abundance data

260 were spread across the different management zones within the SIMP (general use (fishing

261 and trawling permitted): north region 6, south region 18 sites; habitat protection (only

262 fishing permitted): north region 8 , south region 9 sites; and no take zones (fishing and

263 trawling not permitted): north region 5 , south region 8 sites).

264 The final model for each species and group was used to generate predictions of

265 the average prevalence / abundance across each region as a function of the spatial

266 variables and management zones. The predictive performance of models was assessed

267 using 5 fold cross validation. Assessment for prevalence models was based on the mean

268 value across the folds of the Area Under the Receiver Operator Curve (AUC). The AUC

269 quantifies the ability of the model to discriminate between presences and absences in the

270 dataset. AUC values $>0.9$ indicate excellent model performance, $0.7-0.9$ moderate to

271 high performance, $0.5-0.7$ low performance and $\sim 0.5$ indicates performance was no better

272 than random (Barbosa et al. 2013). Estimates of the error of these predictions (AUC

273 standard error) were also generated. Assessment for abundance model was based on the

274 mean value across folds of the proportion of variance explained by the final model, here

275 after referred to as D-squared (Guisan and Zimmerman, 2000). Both the AUC and the D-

276 squared were calculated using the modEvA package (Barbosa et al. 2013).

277 Integrating approaches to systematic conservation planning

278 1) Ranking environmental surrogates

279 The mean distribution of fish across each region was predicted for each species

280 and functional group. Environmental variables were ranked according to the number of

281 final models in which each variable was retained (i.e. a variable retained in all final

282 models would rank 100\%). 
Marxan is the most widely used software for spatial conservation planning

285 globally (Ball 2009). Marxan is a tool to guide systematic planning, it works by allowing

286 an objective spatial optimisation of the areas that should be protected and assessing the

287 trade-offs between the proportion of species conserved successfully and the related cost

288 (Ball et al. 2009). Marxan.io is a web application where users can use Marxan and upload

289 their datasets, run Marxan, edit parameters, run parameter tests, visualise output maps,

290 figures and tables, and publicly share datasets (Watts 2016). We compared seven

291 different conservation scenarios that used either HCS (\% area of each habitat) or SDM

292 (\% abundance/occurrence of each species/functional group) as conservation targets in

293 Marxan.io (Watts and Possingham 2013), (Table 3).

294 North and south regions were merged together and the non-reef areas (i.e. islands,

295 unconsolidated substrata) were excluded. Data available at finer scales than that of the

296 planning units $(250 \times 250 \mathrm{~m})$ were averaged across all cells within each planning unit

297 (total 1603 planning units), and values were standardized proportionally on a scale from 0

$298-1$. The boundary length modifier, which controls the amount of clumping (0.04); the

299 target, which sets the amount of a species/habitat to protect (21\%); and the penalty factor,

300 which penalizes not meeting the target $(0.3)$; were held constant across scenarios. The

301 key question this study investigated was comparing the type of conservation target used

302 (SDMs vs HCS), rather than the variation in conservation scenarios due to variation in

303 either of these values, thus these values were held constant to avoid confounding effects.

304 These values were selected following both global standards, such as the Convention on

305 Biological Diversity Aichi Target 11, which calls for at least $10 \%$ of marine and coastal

306 zones to be protected by 2020 (UNEP 2012, https://www.cbd.int/sp/targets/), and a 
307 sensitivity analyses performed in marxan.io, which tested the trade-off between different

308 levels of protection (target) and the cost of protecting that proportion of the conservation

309 feature (Watts 2016). We allowed the sensitivity analyses to test values between 10\% -

$31030 \%$, and the optimal value was $21 \%$. Existing zones were not taken into account and

$311 \quad 10,000$ iterations were run for each scenario.

312 Table 3 Summary of the seven scenarios tested in this study. The dashed lines separate

313 the types of scenarios (HCS, SDMs and combined). HCS: habitat classification scheme,

314 SDM: species distribution model.

\begin{tabular}{lll}
\hline Scenario & Details of conservation feature & Rational \\
\hline 1. HCS & $\begin{array}{l}\text { HCS based on three depth regions, } \\
\text { and three distances from shore, } \\
\text { resulting in 7 classes. }\end{array}$ & $\begin{array}{l}\text { All variables required } \\
\text { can be obtained at } \\
\text { negligible expense to } \\
\text { managers. }\end{array}$ \\
2. HCS + bathymetry & $\begin{array}{l}\text { HCS plus a bathymetric map of the } \\
\text { standard deviation of depth, a proxy } \\
\text { of habitat structural complexity. }\end{array}$ & $\begin{array}{l}\text { The HCS does not } \\
\text { include any metric of } \\
\text { structural complexity. }\end{array}$ \\
\hline 3. HCS + SDMall & $\begin{array}{l}\text { HCS plus SDMs for 9 species of fish } \\
\text { and 5 functional groups (Table 1). }\end{array}$ & Scenario comparison \\
4. HCS + SDMgroups & $\begin{array}{l}\text { HCS plus SDMs for 5 fish functional } \\
\text { groups (Table 1). }\end{array}$ & Scenario comparison \\
5. SDMall & $\begin{array}{l}\text { SDM for 9 fish species and 5 } \\
\text { functional groups (Table 1). }\end{array}$ & Scenario comparison \\
6. SDMgroups & $\begin{array}{l}\text { SDMs for 5 fish functional groups } \\
\text { (Table 1). }\end{array}$ & Scenario comparison \\
7. SDM & SDMs for 9 fish species (Table 1). & Scenario comparison \\
\hline
\end{tabular}

316 Scenarios were compared in three ways. Firstly, we visualized differences

317 between scenarios using the Marxan frequency output maps and a nonmetric

318 multidimensional scaling plot (nMDS). Secondly, we statistically assessed selection

319 frequency differences between scenarios by planning unit using paired Wilcoxon non-

320 parametric pair-difference test. Thirdly, we compared scenarios using the proportion of 
321 targets protected (species, functional groups and habitat types) and the total area required

322 for conservation under each scenario. The larger the area required for conservation the

323 higher the cost of that scenario.

324 3) Integrating multiple scenarios with local knowledge

325 It is crucial to involve stakeholders to interpret the results of the quantitative

326 analyses if conservation of any area is to be successful. Using expert knowledge to

327 interpret and integrate the results of spatial quantitative approaches like the one presented

328 here has several advantages: it allows for flexibility in discussions about which areas to

329 protect, it allows for the incorporation of knowledge that was not captured during the

330 quantitative process, it increases the probability of compliance by stakeholders once

331 zoning is implemented.

332 We developed a conceptual decision framework to guide the integration of

333 outputs from multiple scenarios using SDM and HCS as conservation targets with local

334 knowledge. This framework included developing spatial layers that showed important

335 areas for conservation values and extractive uses. These layers were based on local

336 knowledge synthesised during meetings and from use databases. Local knowledge was

337 derived from a broad range of scientists, natural resource managers with at least 10 years

338 of experience working in the SIMP region and local stakeholders. Local knowledge

339 helped guide the integration of the results from multiple scenarios following four steps:

340 conservation objectives definition (Brown et al. 2015), spatial solutions assessment,

341 solution integration with local knowledge, and adaptation (Game et al. 2013; Mangubhai

342 et al. 2015). 
344 All focal species and functional groups were recorded across both regions. A total of

345152 fish species were recorded across both regions (96 species in the north and 114 in the

346 south). From these, 24 were target predators, nine piscivores, eight benthic sharks, 22

347 subtropical endemics, four threatened and protected, 18 Labrids, and 67 were not

348 allocated to any of our focal functional groups. Maps of the predicted distribution of nine

349 species and five functional groups (Table 1) were produced (Supplementary Fig. S1).

350 1) Ranking environmental surrogates

351 Predictive performance was consistent between regions. AUC, which indicate the

352 ability of a model to distinguish presences from absences, for individual SDMs ranged

353 from low (0.60) to excellent (0.97). The AUC for benthic sharks SDMs had high

354 performance (0.80), while the piscivores SDM performed moderately (0.66). D-squared,

355 which indicates the predictive accuracy of abundance SDM through cross-validation,

356 ranged from just good (0.10) to excellent (0.67) for species and functional groups (Table

357 4).

358 Despite the strong relationship between fish distributions and environmental variables,

359 the direction and magnitude of responses varied for each response and predictor

360 combination, for example depth had a positive influence on target predators, but a

361 negative influence on target piscivores. Generally, the nine fish species were more

362 abundant/prevalent at greater depths and further from shore. Three of the five fish

363 functional groups were more abundant in shallower waters (target predators, benthic

364 sharks and Labrids), target piscivores were more abundant in deeper waters, and

365 endemics abundance was unrelated to depth. Abundance and prevalence of piscivores,

366 predators and Labrids was greater around more complex reefs (Table S2, Fig. 2). 
367 Table 4 Statistics for the distribution models for five fish groups and nine species of 368 commercial or conservation importance (separated by solid line). Values of deviance 369 explained by model are $\mathrm{D}^{2}$ expressed as percentage, and for predictive accuracy

370 evaluated by cross-validation are mean (SD), and coloured according to model predictive

371 accuracies: bold font excellent, black font high and grey font low (see methods).

\begin{tabular}{|c|c|c|c|c|c|}
\hline \multicolumn{3}{|c|}{ Summary statistics of distribution models } & \multirow{2}{*}{$\begin{array}{c}\begin{array}{c}\text { Deviance } \\
\text { explained }\end{array} \\
\text { Adjusted } D^{2}\end{array}$} & \multicolumn{2}{|c|}{ Predictive accuracy } \\
\hline Species or group & Model type & Region & & $\mathbf{D}^{2}$ & AUC \\
\hline \multirow{2}{*}{ Target predators } & \multirow{2}{*}{$\begin{array}{l}\text { Abundance (negative } \\
\text { binomial) }\end{array}$} & $\mathrm{N}$ & $11 \%$ & $0.16(0.10)$ & NA \\
\hline & & S & $25 \%$ & $0.10(0.05)$ & NA \\
\hline \multirow{2}{*}{$\begin{array}{l}\text { Subtropical } \\
\text { endemics }\end{array}$} & \multirow{2}{*}{$\begin{array}{l}\text { Abundance (negative } \\
\text { binomial) }\end{array}$} & $\mathrm{N}$ & $20 \%$ & $0.25(0.21)$ & NA \\
\hline & & S & $12 \%$ & $0.23(0.12)$ & NA \\
\hline \multirow{2}{*}{ Labrids } & \multirow{2}{*}{ Abundance (poisson) } & $\mathbf{N}$ & $57 \%$ & $0.46(0.24)$ & NA \\
\hline & & $\mathbf{S}$ & $49 \%$ & $0.57(0.02)$ & NA \\
\hline \multirow{2}{*}{ Target piscivores } & \multirow{2}{*}{ Prevalence } & $\mathrm{N}$ & $20 \%$ & NA & $0.67(0.03)$ \\
\hline & & $S$ & $5 \%$ & NA & $0.65(0.11)$ \\
\hline \multirow{2}{*}{ Benthic sharks } & \multirow{2}{*}{ Prevalence } & $\mathrm{N}$ & $24 \%$ & NA & $0.80(0.1)$ \\
\hline & & $S$ & $25 \%$ & NA & $0.79(0.15)$ \\
\hline \multirow{2}{*}{ Snapper } & $\begin{array}{c}\text { Abundance (negative } \\
\text { binomial) }\end{array}$ & $\mathrm{N}$ & $10 \%$ & $0.17(0.18)$ & NA \\
\hline & $\begin{array}{c}\text { Abundance } \\
\text { (hierarchical poisson) }\end{array}$ & S & $34 \%$ & $0.22(0.21)$ & NA \\
\hline \multirow{2}{*}{$\begin{array}{l}\text { Black spotted } \\
\text { goatfish }\end{array}$} & \multirow{2}{*}{$\begin{array}{l}\text { Abundance (negative } \\
\text { binomial) }\end{array}$} & $\mathrm{N}$ & $34 \%$ & $0.28(0.29)$ & NA \\
\hline & & $S$ & $26 \%$ & $0.26(0.07)$ & NA \\
\hline \multirow{2}{*}{ Maori wrasse } & \multirow{2}{*}{ Abundance (poisson) } & $\mathbf{N}$ & $74 \%$ & $0.67(0.11)$ & NA \\
\hline & & $\mathbf{S}$ & $63 \%$ & $0.54(0.09)$ & NA \\
\hline $\begin{array}{l}\text { Crimson banded } \\
\text { wrasse }\end{array}$ & Abundance (poisson) & $\mathbf{N} \& \mathbf{S}$ & $48 \%$ & $0.48(0.14)$ & NA \\
\hline \multirow{2}{*}{ Blind shark } & \multirow{2}{*}{ Prevalence (binomial) } & $\mathrm{N}$ & $25 \%$ & NA & $0.87(0.1)$ \\
\hline & & $\mathbf{S}$ & $30 \%$ & NA & $0.94(0.07)$ \\
\hline \multirow{2}{*}{ Pearl perch } & \multirow{2}{*}{ Prevalence (binomial) } & $\mathrm{N}$ & $39 \%$ & NA & $0.72(0.17)$ \\
\hline & & $S$ & $13 \%$ & NA & $0.72(0.14)$ \\
\hline \multirow[b]{2}{*}{ Venus tuskfish } & Prevalence (binomial) & $\mathrm{N}$ & $55 \%$ & NA & $0.89(0.08)$ \\
\hline & $\begin{array}{c}\text { Prevalence } \\
\text { (quasibinomial) }\end{array}$ & $S$ & $52 \%$ & NA & $0.85(0.08)$ \\
\hline \multirow[b]{2}{*}{ Tarwhine } & Prevalence (binomial) & $\mathrm{N}$ & $21 \%$ & NA & $0.76(0.19)$ \\
\hline & $\begin{array}{c}\text { Prevalence } \\
\text { (quasibinomial) }\end{array}$ & $S$ & $49 \%$ & NA & $0.73(0.12)$ \\
\hline \multirow{2}{*}{ Grey morwong } & \multirow{2}{*}{ Prevalence (binomial) } & $\mathrm{N}$ & $40 \%$ & NA & $0.81(0.12)$ \\
\hline & & $S$ & $48 \%$ & NA & $0.83(0.15)$ \\
\hline
\end{tabular}


All eight variables tested were important predictors of fish distributions (both

373 prevalence and abundance), however, depth was the most important variable and was

374 retained in $80 \%$ of all final models (Fig. 2). Distance from shore influenced $66 \%$ of

375 species and $40 \%$ of functional groups; while latitude and zone were related to $55 \%$ of the

376 species and $40 \%$ of the functional groups. Fractal dimensions influenced $66 \%$ of the

377 species, but only $20 \%$ of the functional groups. Other habitat structure metrics were also

378 important predictors: depth standard deviation and reef area were significantly related to

$37944 \%$ of the species, and $40 \%$ and $20 \%$ of the functional groups, respectively. Curvature

380 was the variable of least influence, retained in $40 \%$ of the functional groups and $22 \%$ of

381 the species' models (Table 4, Fig. 2).

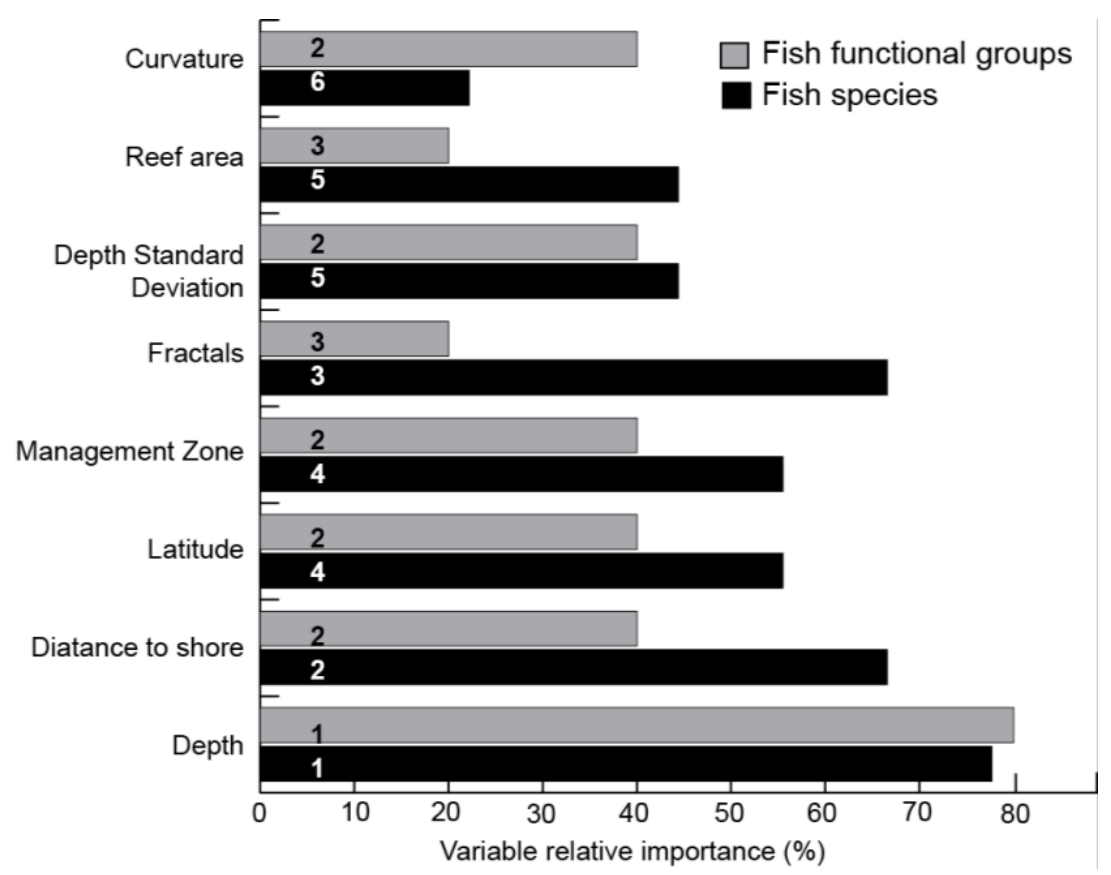

383 Figure 2 Relative importance of explanatory variables of both prevalence and abundance

384 models. The numbers inside each bar represent the ranking of each environmental

385 variable according to the number of final models each variable was retained in. For

386 instance, if a variable had been retained in all final models it would have a value of $100 \%$,

387 indicating it was significantly related to all focal fish species / functional groups. Thus 
388 the higher the $\mathrm{x}$-axis value, the more useful a variable is to describe fish spatial patterns

389 of abundance and prevalence. Management zone = no take.

390 2) Conservation planning scenario comparison

391 The seven scenarios clearly separated in two groups, those using the HCS and those

392 using SDM as conservation targets (Fig. S2-S4). When both the HCS and the SDM were

393 combined into one scenario (Table 3) the resulting selection was similar to that of

394 scenarios with only HCS (Fig. 3), because the HCS scenarios required more area to

395 achieve the conservation target.

396 The Wilcoxon-test found no significant difference between the three scenarios

397 including SDM $(\mathrm{W}=1266300$, $\mathrm{p}$-value $=0.4535)$, nor between the four scenarios

398 including HCS $(\mathrm{W}=1288900$, $\mathrm{p}$-value $=0.8763)$; but detected strong significant

399 differences between any combination of SDM vs HCS scenarios ( $\mathrm{W}=691200$, $\mathrm{p}$-value

$400<0.05)$. Thus, we focus our discussion and results on two scenarios: the HCS and the

401 SDM.

402 Scenarios using only the HCS applied a blanket approach to biodiversity

403 representation and required the protection of three times more area than the SDM

404 scenarios to achieve the conservation target (18\% vs. $6.5 \%$ total area); but achieved

405 protecting at least $21 \%$ of all habitat types, and $24-43 \%$ of focal species and functional

406 groups (Fig. 3, 4 and Fig. S4). The SDM scenario protected at least $21 \%$ of the predicted

407 abundance/occurrence of the focal species and functional groups, but only protected $21 \%$

408 of one habitat type, with less than $7 \%$ of any other habitat receiving protection (Fig. 4).

409 For example, when protecting all focal species and functional groups, none of the

410 intermediate inshore reef was protected, potentially threatening species that live there but 
411 were not recorded in this study. The SDM scenarios adequately represented fish of

412 commercial and conservation importance, including a biodiversity surrogate group

413 (Labrids), by protecting a much smaller area; yet at the risk of failing to protect biota that

414 was not captured by the SDM (i.e. benthic biota). The SDM solution provided less spatial

415 flexibility than the HCS solution.

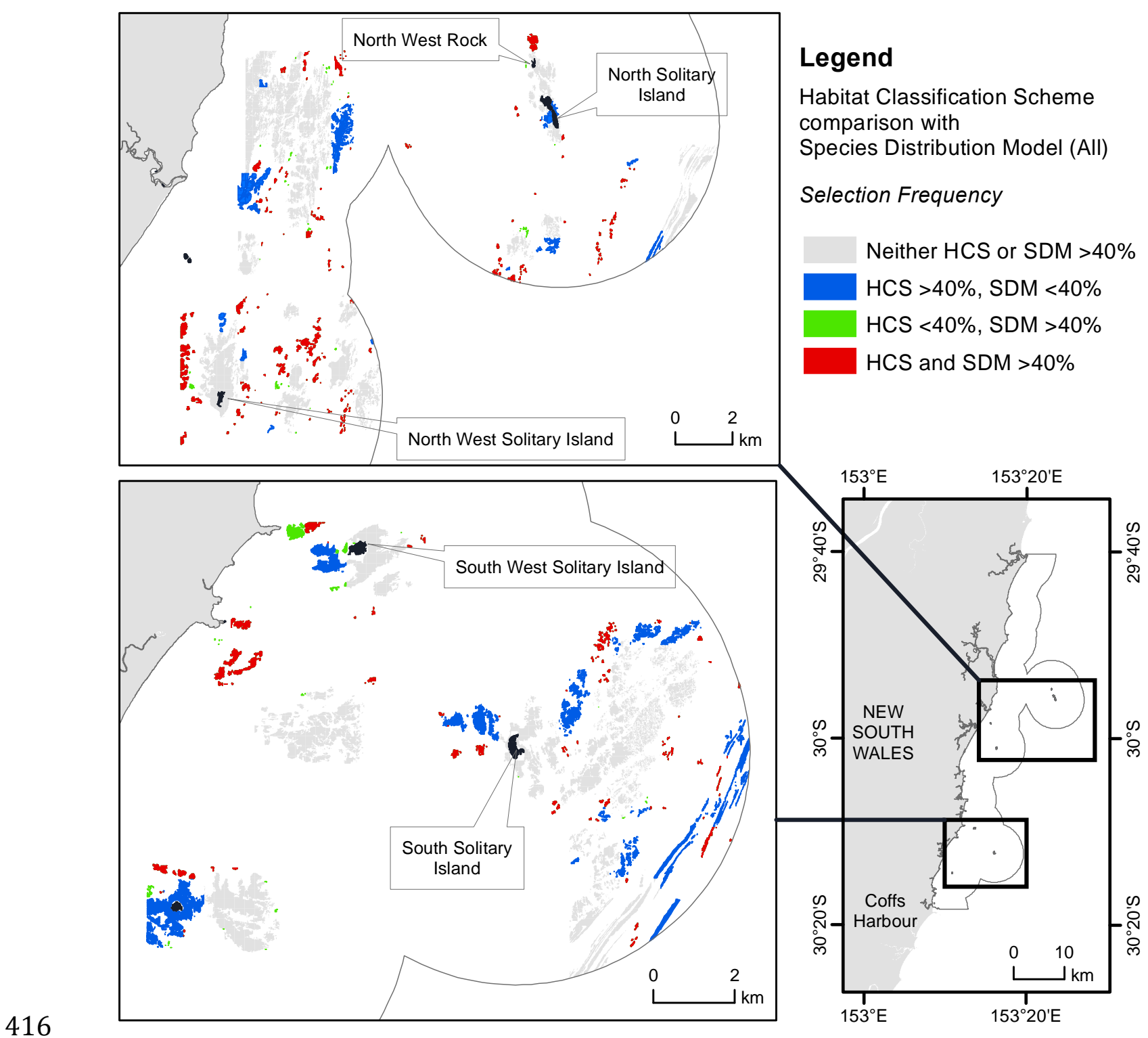

417 Figure 3 Comparison of Marxan.io scenarios using habitat classification scheme (HCS)

418 and species distribution models (SDM) as conservation targets. Map denotes areas 
419 frequently selected (in at least $40 \%$ of the 10,000 iterations) for conservation by each 420 scenario (HCS - blue, SDM - green), and areas selected by both scenarios (red). The 421 HCS selected $18 \%$ of the area, while the SDM scenario selected $6.5 \%$ of the area, and 422 there was an overlap of $5.8 \%$ between scenarios (Table S3).
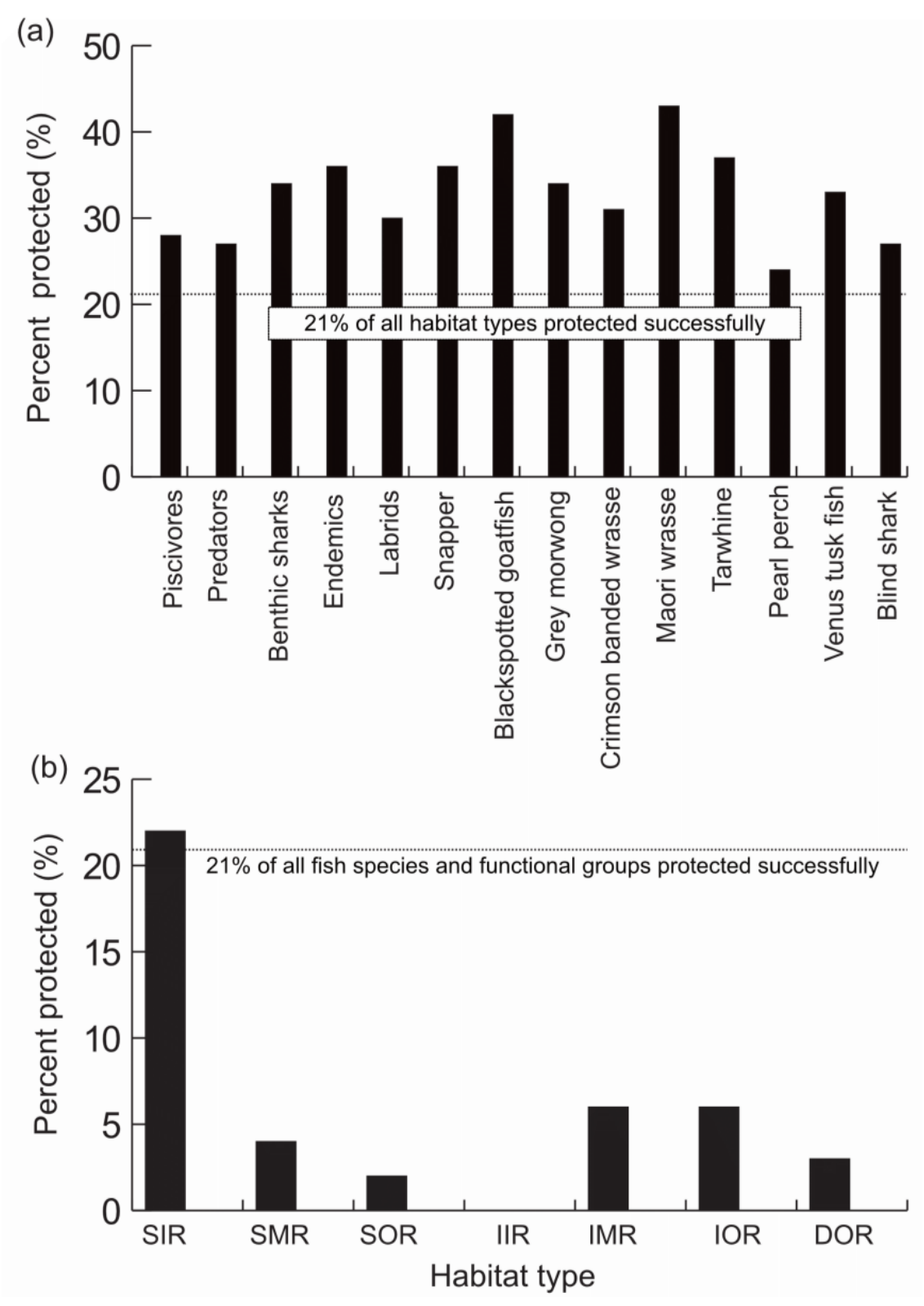

424 Figure 4 Percent of conservation feature protected by scenarios using (a) habitat

425 classification scheme or (b) distribution models as conservation targets. The dashed line

426 in both graphs denotes the target $21 \%$ to be protected by that scenario. The bars represent

427 the additional percent protected for other conservation features not considered in that 
428 scenario, for instance in (a) only $21 \%$ of each habitat type was targeted for conservation, 429 but also $25-42 \%$ of each fish species and functional group were protected. SIR: shallow 430 inshore reef, SMR: shallow mid shelf reef, SOR: shallow offshore reef, IIR: intermediate 431 inshore reef, IMR: intermediate mid shelf reef, IOR intermediate offshore reef, and DOR: 432 deep offshore reef.

433 No scenario protected known biodiversity hot-spots ( $\sim 0.1 \%$ of total area). Thus, 434 given there are advantages and disadvantages to both approaches and that they are not 435 mutually exclusive, a conceptual framework to integrate HCS and SDM solutions with 436 local knowledge was developed (Fig. 5).

437 


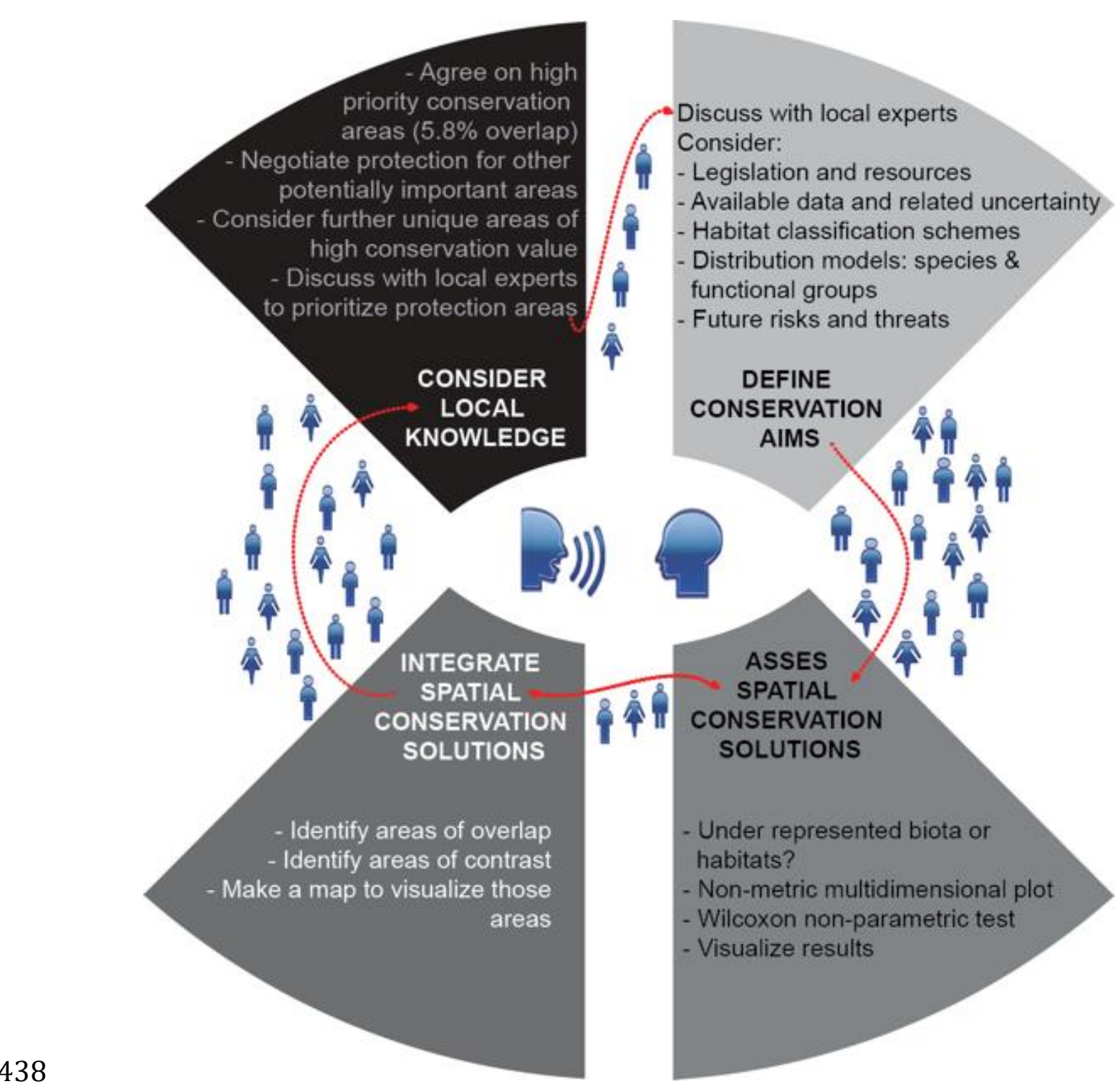

439 Figure 5 Conceptual decision framework to guide the integration of outputs from

440 multiple systematic spatial planning scenarios using species distribution models and

441 habitat classification schemes as conservation targets in marine ecosystems.

442 3) Integrating multiple scenarios with local knowledge

443 We integrated conservation solutions by identifying overlapping areas with high-

444 frequency selection across scenarios. In this study, the 5.8\% overlap (of the total study

445 area) between scenarios highlighted the core area with high-priority for conservation (Fig.

446 3). The decision framework included using this map alongside maps of important areas 
447 for extractive and non-extractive uses (Fig. 6), as identified by local knowledge through

448 stakeholder meetings. This identified gaps and guided further prioritization of areas to be

449 protected amongst the remaining 13\% frequently selected areas in the HCS scenario

450 (Fig. 3). Thus, the core area identified as high-priority for conservation was then

451 extended to $10 \%$, as per Convention on Biological Diversity recommendations of at least

$45210 \%$ of each habitat type be represented in highly protected areas (UNEP 2012). In an

453 actual planning situation, these integrated maps showing core areas for protection (Fig. 3

454 and 6), would provide an effective platform for on-going discussion and negotiations at

455 stakeholder meetings held to spatially plan conservation zones in a marine park.
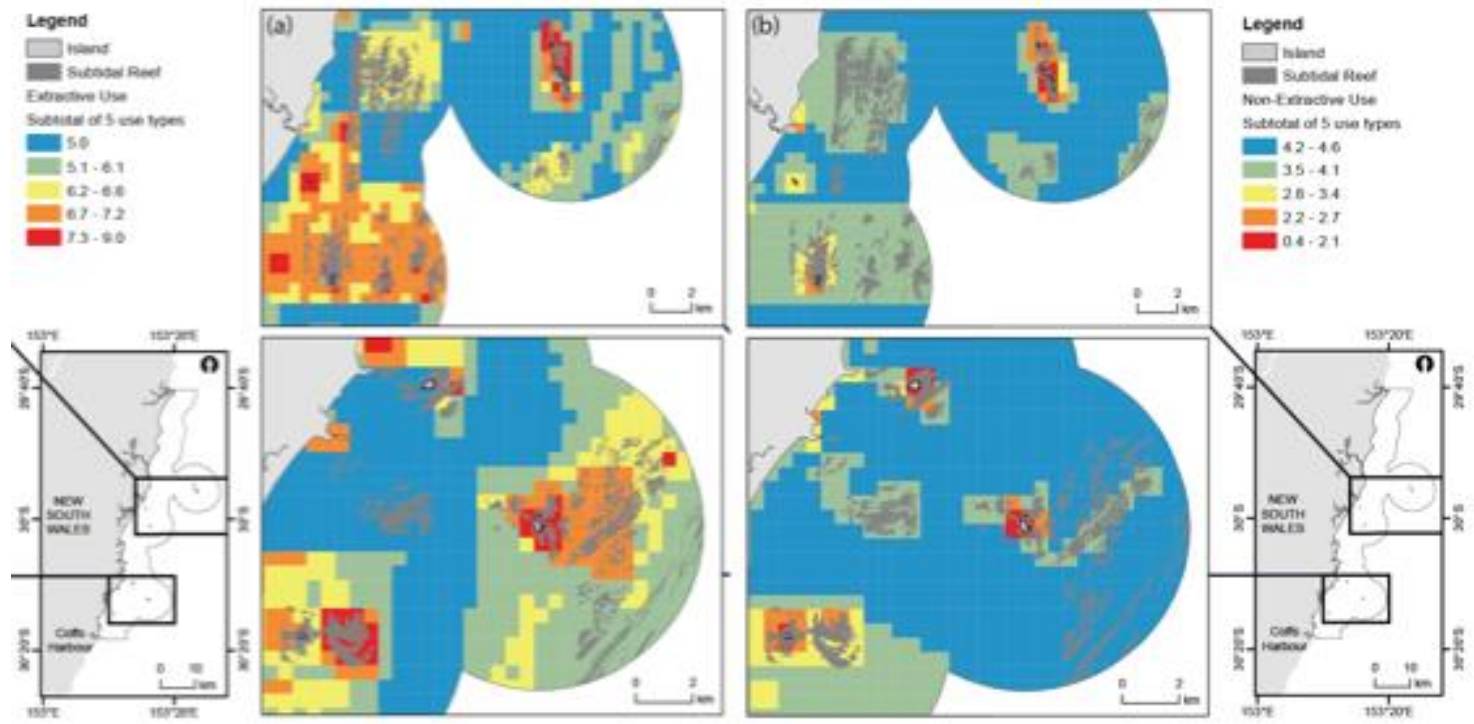

457 Figure 6 (a) Extractive (i.e. fishing) and (b) non-extractive (i.e. diving) uses of the SIMP, as per stakeholder meetings and use data, numbers denote the number of users.

\section{Discussion}

This study advanced systematic conservation planning of marine ecosystems on

461 three fronts. Firstly, it ranked surrogates and assessed their utility in conservation

462 planning; secondly, it quantitatively compared conservation trade-offs between scenarios

463 using HCS and SDM as targets; and thirdly, it developed a decision framework to guide 
464 the integration of both approaches with local knowledge. Here, we demonstrate how

465 these three steps can be applied to a data-poor highly biodiverse marine ecosystem using

466 conservation aims that are globally common: to protect biodiversity and species of

467 commercial and conservation importance (UNEP 2012).

468 Ranking environmental surrogates

469 The predictive performance of models was consistently good across all species and

470 functional groups. Depth was the most important surrogate, although fractal dimensions

471 and distance from shore were also important. Habitat structure metrics consistently had a

472 positive relationship to fish abundance/occurrence confirming recent findings (Moore et

473 al. 2011). Interestingly, surrogates that are readily obtained (i.e. distance) predicted fish

474 distributions as accurately as surrogates that require high-resolution mapping information

475 (i.e. fractals). This has important practical applications because obtaining high-resolution

476 variables requires relatively expensive data, while quantifying a set of variables from

477 low-resolution datasets has negligible cost. We used high-resolution depth and distance in

478 the SDM, but low-resolution data in the HCS. While the high-resolution variables did

479 improve the models, both robust HCS and SDM could be achieved if these are

480 unavailable using low-resolution data (Malcolm et al. 2011; Moore et al. 2011; Stevens

481 and Connolly 2004).

482 Integrating conservation solutions and local knowledge

483 Using SDM to set conservation targets in data-poor ecosystems can improve

484 conservation planning (Beger et al. 2003), but in isolation SDM also have some

485 conservation risks as not all species can be adequately captured by the models, or the data

486 underlying the models. For example, if the biotic data and associated models only 
487 represent fish assemblages, important benthic biota and invertebrates would not be 488 represented in the SDM scenarios. On the other hand, using only the HCS to set

489 biodiversity targets can be cost-effective compared to collecting raw biotic data (Guisan 490 et al. 2013), but it could also result in a solution that requires a large area to be protected 491 to achieve conservation objectives (Jackson and Lundquist 2016). Additionally, HCS 492 based solely on abiotic surrogates will only coarsely approximate real biodiversity 493 patterns (Giakoumi et al. 2015; Rubidge et al. 2016). Using local knowledge to synthesise 494 conservation planning results obtained by multiple scenarios (both SDM and HCS) can 495 ameliorate these hurdles, and is more likely to cost-effectively represent biodiversity and 496 achieve secondary conservation goals simultaneously (Klein et al. 2008).

497 Combining the outputs of multiple scenarios and socio-economic uses highlighted 498 overlapping areas. This offers flexibility at the planning negotiation table, for discussion 499 between managers and stakeholders, creating room for negotiation while ensuring the 500 protection of the most important areas simultaneously. For instance, in this study the $5015.8 \%$ areas frequently selected by both the HCS and the SDM scenarios would be 502 prioritised for protection in 'no take' zones, and stakeholders could negotiate around the 503 remaining identified areas (in this study remaining $13 \%$ identified for protection by the 504 HCS) using the maps that highlight extractive and non-extractive uses (Fig. 6).

505 None of the seven scenarios protected unique sites of known high biodiversity 506 (Malcolm et al. 2010). This is not unexpected, as these sites have not been sampled as 507 part of this study so their biotic and environmental features were not captured by either 508 the HCS or the SDM. Such sites should be fully protected to maximise the chance of 509 including rare species or functional groups that may inhabit only these areas (Beger et al. 
510 2003). We suggest managers protect unsurveyed, but known, biodiversity hotspots

511 regardless of the systematic spatial conservation solutions.

512 It is important to highlight that when SDM are not available, effective conservation

513 planning scenarios can be achieved using only HCS, which are essential for correcting

514 biases and filling gaps in knowledge (Brooks et al. 2004). Applying a precautionary

515 approach to conservation planning is advised, especially in data-poor ecosystems (Groves

516 and Game 2016).

$517 \quad$ Game et al. (2017) showed the need for methodologies that enable the rapid 518 incorporation of both local and expert knowledge, particularly in data-poor systems,

519 such as the fuzzy logic models. This study developed advanced SDM and a robust HCS

520 to inform conservation planning. We tested and ranked eight environmental surrogates of

521 fish distributions, including fish functional groups, which can be transferred to other

522 marine ecosystems (Brown and Mumby 2014). Combining both scenario types,

523 particularly interpreted in the context of local knowledge, will identify effective

524 conservation solutions and add flexibility to negotiations between managers and

525 stakeholders. In turn, these discussions will maximize the likelihood of successful

526 conservation planning by involving stakeholders early in the planning process (Groves

527 and Game 2016) and allow rapid responses to environmental and social changes (Brown

528 et al. 2012).

\section{Acknowledgements}

530 This project was supported by the University of Sydney, the NSW Department of

531 Primary Industries and Australia's Integrated Marine Observing System (IMOS),

532 partially funded by the Department of Innovation, Industry, Science and Research 
533 through the National Collaborative Research Infrastructure Scheme and the Education

534 Investment Fund, and the Marine Biodiversity Hub, a collaborative partnership supported

535 through funding from the Australian Government's National Environmental Research

536 Program (NERP).

537 Data availability: all environmental data are available at https://catalogue-

538 imos.aodn.org.au/geonetwork/srv/eng/metadata.show?uuid=60160b01-8ffc-45ce-a6f4-

539 ee70ce391ec6

540 
1. Ball, I.R., H.P. Possingham, and M. Watts. 2009. Marxan and relatives: Software for spatial conservation prioritisation. Chapter 14: Pages 185-195 in Spatial conservation prioritisation: Quantitative methods and computational tools. Eds Moilanen, A., K.A. Wilson, and H.P. Possingham. Oxford University Press, Oxford, UK.

2. Ballantine W., Langlois T. (2008) Marine reserves: the need for systems. Hydrobiologia 606, 35-44.

3. Ban N.C. (2009) Minimum data requirements for designing a set of marine protected areas, using commonly available abiotic and biotic datasets. Biodivers Conserv 18, 1829-1845.

4. Barbosa M.A., Real R., Muñoz A., Brown J.A. (2013) New measures for assessing model equilibrium and prediction mismatch in species distribution models. Divers Distrib 19, 1333-1338.

5. Barrett N., Edgar G., Morton A., Buxton C. (2003) A decade of study in Tasmanian MPAs-Part 2. Fishing Today 16, 2.

6. Beger M., Jones G.P., Munday P.L. (2003) Conservation of coral reef biodiversity: a comparison of reserve selection procedures for corals and fishes. Biol Conserv 111, 53-62.

7. Bjornstad O.N. (2013) ncf: spatial nonparametric covariance functions. $R$ package version 11-5.

8. Bolker B.M., Brooks M.E., Clark C.J., Geange S.W., Poulsen J.R., Stevens M.H.H., White J.S.S. (2009) Generalized linear mixed models: a practical guide for ecology and evolution. Trends Ecol Evol 24, 127-135.

9. Brooks T., Fonseca D.A., Gustavo A.B., Rodrigues A.S. (2004) Species, data, and conservation planning. Conservation Biology 18, 1682-1688.

10. Brown C.J., Bode M., Venter O., Barnes M.D., McGowan J., Runge C.A., Watson J.E., Possingham H.P (2015) Effective conservation requires clear objectives and prioritizing actions, not places or species. Proceedings of the National Academy of Sciences 112, E4342- E4342.

580

11. Brown C.J., Fulton E.A., Possingham H.P., Richardson A.J. (2012) How long can fisheries management delay action in response to ecosystem and climate change? Ecological Applications 22, 298-310.

12. Brown C.J., Mumby P.J. (2014) Trade-offs between fisheries and the conservation of ecosystem function are defined by management strategy. Front Ecol Environ 12, 324-329.

13. Cappo M., Harvey E.S., Malcolm H., Speare P. (2003) Potential of video techniques to monitor diversity, abundance and size of fish in studies of Marine Protected Areas. pp. 455-464 in J.P. Beumer, A. Grant, D.C. Smith 
581

582

583

584

585

586

587

588

589

590

591

592

593

594

595

596

597

598

599

600

601

602

603

604

605

606

607

608

609

610

611

612

613

614

615

616

617

618

619

620

621

editors. Aquatic Protected Areas - what works best and how do we know? World Congress on Aquatic Protected Areas proceedings, Cairns, Australia.

14. Cook, R. \& Auster, P. (2006) Developing alternatives for optimal representation of seafloor habitats and associated communities in Stellwagen Bank National Marine Sanctuary. Marine Sanctuaries Conservation Series pp. 24. U.S. Department of Commerce, National Oceanic and Atmospheric Administration, Office of National Marine Sanctuaries

15. Cowling, R.M., Pressey, R.L., Sims-Castley, R., le Roux, A., Baard, E., Burgers, C.J. \& Palmer, G. (2003) The expert or the algorithm? - comparison of priority conservation areas in the Cape Floristic Region identified by park managers and reserve selection software. Biological Conservation, 112, 147-167.

16. Elith J., Graham C.H. (2009) Do they? How do they? WHY do they differ? On finding reasons for differing performances of species distribution models. Ecography 32, 66-77.

17. Elith J., Leathwick J.R. (2009) Species distribution models: ecological explanation and prediction across space and time. Annual Review of Ecology, Evolution, and Systematics 40, 677-697.

18. Fernandes, L., Day, J., Lewis, A., Slegers, S., Kerrigan, B., Breen, D., Cameron, D., Jago, B., Hall, J., Lowe, D., Innes, J., Tanzer, J., Chadwick, V., Thompson, L., Gorman, K., Simmons, M., Barnett, B., Sampson, K., De'ath, G., Mapstone, B., Marsh, H., Possingham, H., Ball, I., Ward, T., Dobbs, K., Aumend, J., Slater, D. \& Stapleton, K. (2005) Establishing representative no-take areas in the Great Barrier Reef; large-scale implementation of theory on marine protected areas. Conservation Biology, 19, 1733-1744.

19. Ferrier, S. (2002) Mapping spatial pattern in biodiversity for regional conservation planning: Where to from here? Systematic Biology, 51, 331-363.

20. Game E.T., Bremer L.L., Calvache A., Calvache A., Moreno P.H., Vargas A., Rivera B., Rodriguez, L.M. (2017) Fuzzy Models to Inform Social and Environmental Indicator Selection for Conservation Impact Monitoring. Conserv Lett, doi: 10.1111/conl.12338.

21. Game E.T., Kareiva P., Possingham H.P. (2013) Six common mistakes in conservation priority setting. Conservation Biology 27, 480-485.

22. Giakoumi S., Brown C.J., Katsanevakis S., Saunders M.I., Possingham H.P. (2015) Using threat maps for cost-effective prioritization of actions to conserve coastal habitats. Mar Policy 61, 95-102.

23. Groves C., Game E.T. (2016) Conservation Planning: Informed Decisions for a Healthier Planet. W. H. Freeman, Uniterd Kingdom.

24. Guisan A., Tingley R., Baumgartner J.B., Naujokaitis-Lewis, I. Sutcliffe, P.R., Tulloch A.I., Regan T.J., Brotons L., McDonald-Madden E., Mantyka-Pringle C., Martin T.G., (2013) Predicting species distributions for conservation decisions. Ecology letters 16, 1424-1435. 
25. Guisan A., Zimmermann N.E. (2000) Predictive habitat distribution models in ecology. Ecological Modelling 135, 147-186.

26. Harasti D., Malcolm H., Gallen C., Coleman M.A., Jordan A., Knott N.A. (2015) Appropriate set times to represent patterns of rocky reef fishes using baited video. Journal of Experimental Marine Biology and Ecology 463, 173-180.

27. Hardinge J., Harvey E.S., Saunders B.J., Newman S.J. (2013) A little bait goes a long way: the influence of bait quantity on a temperate fish assemblage sampled using stereo-BRUVs. Journal of Experimental Marine Biology and Ecology 449, 250-260.

28. Harriott, V.J., Smith, S.D.A. \& Harrison, P.L. (1994) Patterns of coral community structure of subtropical reefs in the Solitary Islands Marine Reserve, Eastern Australia. Marine Ecology Progress Series, 109, 67-76.

29. Henry, G., Matthews, J. \& Kelly, E. (1996) Recreational fishing competition survey of Solitary Islands Marine Park. NSW Fisheries Report to the National Fishcare Program.

30. Jackson S.E., Lundquist C.J. (2016) Limitations of biophysical habitats as biodiversity surrogates in the Hauraki Gulf Marine Park. Pac Conserv Biol 22, 159-172.

31. Johnston A., Fink D., Reynolds M.D., Hochachka W.M., Sullivan B.L., Bruns N.E., Hallstein E., Merrifield M.S., Matsumoto S., Kelling, S. (2015) Abundance models improve spatial and temporal prioritization of conservation resources. Ecological Applications 25, 1749-1756.

32. Jordan A., Davies P., Ingleton T., Foulsham E., Neilson J., Pritchard T. (2010) Seabed habitat mapping of the continental shelf of NSW. p. 207. Sydney, NSW.

33. Jordan A., Lucieer V., Lawler M. (2005) Linking habitat mapping with fisheries assessment in key commercial fishing grounds.

34. Klein C.J., Brown C.J., Halpern B.S., Segan D.B., McGowan J., Beger M., Warson J.E. (2015) Shortfalls in the global protected area network at representing marine biodiversity. Scientific reports 5, 17539.

35. Klein, C.J., Chan, A., Kircher, L., Cundiff, A.J., Gardner, N., Hrovat, Y., Scholz, A., Kendall, B.E. \& Airame, S. (2008a) Striking a Balance between Biodiversity Conservation and Socioeconomic Viability in the Design of Marine Protected Areas. 22, 691-700.

36. Klein, C.J., Steinback, C., Scholz, A.J. \& Possingham, H.P. (2008b) Effectiveness of marine reserve networks in representing biodiversity and minimizing impact to fishermen: a comparison of two approaches used in California, Conservation Letters, 1, 44-51.

37. Leslie, H. (2005) A Synthesis of Marine Conservation Planning Approaches. Conservation Biology, 19, 1701-1713.

38. Leslie, H., Ruckelshaus, M., Ball, I., Andelman, S. \& Possingham, H. (2003) Using siting algorithims in the design of marine reserve networks. Ecological Applications, 13, S185-S198. 
664

665

666

667

668

669

670

671

672

673

674

675

676

677

678

679

680

681

682

683

684

685

686

687

688

689

690

691

692

693

694

695

696

697

698

699

700

701

702

703

704

705

39. Levin, N., Watson, J.E.M., Joseph, L.N., Grantham, H.S., Hadar, L., Apel, N., Perevolotsky, A., DeMalach, N., Possingham, H.P. \& Kark, S. (2013) A framework for systematic conservation planning and management of Mediterranean landscapes, Biological Conservation, 158, 371-383.

40. Malcolm H.A., Foulsham E., Pressey R.L., Jordan A., Davies P.L., Ingleton T., Johnstone N., Hessey S., Smith S.D (2012) Selecting zones in a marine park: Early systematic planning improves cost-efficiency; combining habitat and biotic data improves effectiveness. Ocean and Coastal Management 59, 1-12.

41. Malcolm H.A., Jordan A., Smith S.D.A. (2010) Biogeographical and cross-shelf patterns of reef fish assemblages in a transition zone. Marine Biodiversity 40, 181-193.

42. Malcolm H.A., Jordan A., Smith S.D.A. (2011) Testing a depth-based Habitat Classification System against the pattern of reef fish assemblages $(15-75 \mathrm{~m})$ in a subtropical marine park. Aquatic Conservation: Marine and Freshwater Ecosystems 21, 173-185.

43. Malcolm H.A., Smith S.D.A. (2010) Objective selection of surrogate families to describe reef fish assemblages in a subtropical marine park. Biodiversity and Conservation 19, 3611-3618.

44. Mangubhai S., Wilson J.R., Rumetna L., Maturbongs Y. (2015) Explicitly incorporating socioeconomic criteria and data into marine protected area zoning. Ocean \& Coastal Management 116, 523-529.

45. Margules, C.R. \& Pressey, R.L. (2000) Systematic conservation planning. Nature, 405, 243-253.

46. McCook, L.J., Ayling, T., Cappo, M., Choat, J.H., Evans, R.D., De Freitas, D.M., Heupel, M., Hughes, T.P., Jones, G.P., Mapstone, B., Marsh, H., Mills, M., Molloy, F.J., Pitcher, R.C., Pressey, R.L., Russ, G.R., Sutton, S., Sweatman, H., Tobin, R., Wachenfeld, D.R. \& Williamson, D.H. (2010) Adaptive management of the Great Barrier Reef: A globally significant demonstration of the benefits of networks of marine reserves. Proceedings of the National Academy of Science, 107, 18278-18285.

47. Moore C.H., Van Niel K., Harvey E.S. (2011) The effect of landscape composition and configuration on the spatial distribution of temperate demersal fish. Ecography, 34, 425-435.

48. Pressey, R.L. \& Cowling, R.M. (2001) Reserve selection algorithms and the real world. Conservation Biology, 15, 275-277.

49. RCoreTeam. (2014) R: A language and environment for statistical computing. R Foundation for Statistical Computing, Vienna, Austria.

50. Rowling, K., Hegarty, A. \& Ives, M. (2010) Status of fisheries resources in NSW, 2008/09. Industry and Investment NSW.

51. Rubidge E.M., Gale K.S.P., Curtis J.M.R. (2016) Community ecological modelling as an alternative to physiographic classifications for marine conservation planning. Biodivers Conserv 25, 1899-1920. 
706

707

708

709

710

711

712

713

714

715

716

717

718

719

720

721

722

723

724

725

726

727

728

729

730

731

732

733
52. Sarker, S., Justus, J., Fuller, T., Kelley, C., Garson, J. \& Mayfield, M. (2005) Effectiveness of Environmental Surrogates for the Selection of Conservation Area Networks. Conservation Biology, 19, 815-825.

53. Sarker, S., Pressey, R.L., Faith, D.P., Margules, C.R., Fuller, T., Stoms, D.M., Moffett, A., Wilson, K.A., Williams, K.J., Williams, P.H. \& Andelman, S. (2006) Biodiversity conservation planning tools: Present status and challenges for the future. Annu. Rev. Environ. Resour, 31, 123-159.

54. Stevens, T. \& Connolly, R. (2004) Testing the utility of abiotic surrogates for marine habitat mapping at scales relevant to management. Biological Conservation, 119, 351-362.

55. Stewart, R.R., Noyce, T. \& Possingham, H.P. (2003) Opportunity cost of ad hoc marine reserve design decisions: an example from South Australia. Marine Ecology Progress Series, 253, 25-38.

56. UNEP. (2012) Global Environmental Outlook 5. Available from http://web.unep.org/geo/assessments/global-assessments/globalenvironment-outlook-5. Accessed 30 April 2017.

57. Venables W.N., Ripley B.D. (2002) Modern Applied Statistics with S, Fourth Edition, Springer, New York pp. 27-300.

58. Watts M., Possingham H.P. (2013) Marxan.net: Cloud infrastructure for systematic conservation planning. Available from http://marxan.net/. Accessed 30 April 2017.

59. Watts, M.E. 2016. marxan.io: A web app for systematic conservation planning. Revision 46. URL http://marxan.net/marxanio

60. Wood S.N. (2011) Fast stable restricted maximum likelihood and marginal likelihood estimation of semiparametric generalized linear models. Journal of the Royal Statistical Society: Series B (Statistical Methodology) 73, 3-36. 
735 Figure 1 Map of the study area with the Habitat Classification Scheme (HCS)

736 highlighted in colour. The grey line denotes the marine park boundary.

737 Figure 2 Relative importance of explanatory variables. The numbers inside each bar 738 represent the ranking of each environmental variable according to the number of final

739 models each variable was retained in. For instance, if a variable had been retained in all

740 final models it would have a value of $100 \%$, indicating it was significantly related to all

741 focal fish species / functional groups. Thus the higher the $\mathrm{x}$-axis value, the more useful a

742 variable is to describe fish spatial patterns of abundance and prevalence. Management

$743 \quad$ zone $=$ no take.

744 Figure 3 Comparison of Marxan.io scenarios using habitat classification scheme (HCS)

745 and species distribution models (SDM) as conservation targets. Map of the areas

746 frequently selected (in at least $40 \%$ of the 10,000 iterations) for conservation by the HCS

747 (blue) and the SDM (green) scenarios. Red areas were selected by both scenarios at least

$74840 \%$ of the iterations. Only $20 \%$ of the area was selected by either scenario more than

$74940 \%$ of the time, the HCS selected $18 \%$ of the area, while the SDM scenario selected

$7506.5 \%$ of the area, and there was an overlap of $5.8 \%$ between scenarios (Table S3).

751 Figure 4 Percent of conservation feature protected by scenarios using (a) habitat

752 classification scheme or (b) distribution models as conservation targets. The dashed line

753 in both graphs denotes the target $21 \%$ to be protected by that scenario. The bars represent

754 the additional percent protected for other conservation features not considered in that

755 scenario, for instance in (a) only $21 \%$ of each habitat type was targeted for conservation,

756 but also $25-42 \%$ of each fish species and functional group were protected. SIR: shallow

757 inshore reef, SMR: shallow mid shelf reef, SOR: shallow offshore reef, IIR: intermediate 
758 inshore reef, IMR: intermediate mid shelf reef, IOR intermediate offshore reef, and DOR:

759 deep offshore reef.

760 Figure 5 Conceptual decision framework to guide the integration of outputs from

761 multiple systematic spatial planning scenarios using species distribution models and

762 habitat classification schemes as conservation targets in marine ecosystems.

763 Figure 6 (a) Extractive (i.e. fishing) and (b) non-extractive (i.e. diving) uses of the SIMP, 764 as per stakeholder meetings and use data, numbers denote the number of users.

765 


\section{Supplementary information}

767 Table S1 Species placed in each functional group for this study. We looked at threatened 768 and protected species but they were not numerous enough to model, they were considered 769 in the last step of our decision framework when considering unique areas that were not

770 properly represented by the conservation targets.

\begin{tabular}{|c|c|c|}
\hline $\begin{array}{l}\text { Functional } \\
\text { Group }\end{array}$ & Common name & Scientific name \\
\hline $\begin{array}{l}\text { Target } \\
\text { piscivores }\end{array}$ & $\begin{array}{l}\text { Samsonfish } \\
\text { Amberjack } \\
\text { Yellowtail kingfish } \\
\text { Pearl perch } \\
\text { Jewfish, mulloway } \\
\text { Teraglin, trag } \\
\text { Black cod } \\
\text { Scribbled rockcod } \\
\text { Bonito }\end{array}$ & $\begin{array}{l}\text { Seriola hippo } \\
\text { Seriola dumerili } \\
\text { Seriola lalandi } \\
\text { Glaucosoma scapulare } \\
\text { Argyrosomus hololepidotus } \\
\text { Atractoscion aequidens } \\
\text { Epinephelus daemelii } \\
\text { Epinephelus undulatostriatus } \\
\text { Sarda australis }\end{array}$ \\
\hline $\begin{array}{l}\text { Target } \\
\text { predators }\end{array}$ & $\begin{array}{l}\text { Eastern blue groper } \\
\text { Foxfish } \\
\text { Goldspot hogfish } \\
\text { Pigfish } \\
\text { Venus tusk fish } \\
\text { Crimson-banded wrasse } \\
\text { Maori wrasse } \\
\text { Moses perch } \\
\text { Blackspot goatfish } \\
\text { Bream } \\
\text { Snapper } \\
\text { Tarwhine } \\
\text { Chinaman leatherjacket } \\
\text { Sergeant baker } \\
\text { Wirrah } \\
\text { Red morwong } \\
\text { Emperor } \\
\text { Hussar } \\
\text { Southern fusilier } \\
\text { Goldspotted sweetlips } \\
\text { Sweetlips } \\
\text { Cobia } \\
\text { Silver trevally } \\
\text { Grey morwong }\end{array}$ & $\begin{array}{l}\text { Achoerodus viridis } \\
\text { Bodianus frenchii } \\
\text { Bodianus perditio } \\
\text { Bodianus unimaculatus } \\
\text { Choerodon venustus } \\
\text { Notolabrus gymnogenis } \\
\text { Opthalmolepis lineolata } \\
\text { Lutjanus russelli } \\
\text { Parupeneus spilurus } \\
\text { Acanthopagrus australis } \\
\text { Chrysophrys auratus } \\
\text { Rhabdosargus sarba } \\
\text { Nelusetta ayraudi } \\
\text { Aulopus purpurissatus } \\
\text { Acanthistius ocellatus } \\
\text { Cheilodactylus fuscus } \\
\text { Lethrinus sp. } \\
\text { Lutjanus adetii } \\
\text { Paracaesio xanthura } \\
\text { Plectorhinchus flavomaculatus } \\
\text { Plectorhinchus sp } \\
\text { Rachycentron canadum } \\
\text { Pseudocaranx dentex } \\
\text { Nemadactylus douglasi }\end{array}$ \\
\hline $\begin{array}{l}\text { Benthic } \\
\text { sharks }\end{array}$ & $\begin{array}{l}\text { Gulf wobbegong } \\
\text { Ornate wobbegong } \\
\text { Spotted wobbegong } \\
\text { Blindshark }\end{array}$ & $\begin{array}{l}\text { Orectolobus halei } \\
\text { Orectolobus ornatus } \\
\text { Orectolobus maculatus } \\
\text { Brachaelurus waddi }\end{array}$ \\
\hline
\end{tabular}




\begin{tabular}{|c|c|c|}
\hline & $\begin{array}{l}\text { Gummy shark } \\
\text { Created port jackson } \\
\text { Shark } \\
\text { Cat shark } \\
\text { grey nurse shark }\end{array}$ & $\begin{array}{l}\text { Mustelus antarcticus } \\
\text { Heterodontus galeatus } \\
\text { Asymbolus sp } \\
\text { Carcharias taurus }\end{array}$ \\
\hline $\begin{array}{l}\text { Subtropical } \\
\text { endemics }\end{array}$ & $\begin{array}{l}\text { Eastern blue devil } \\
\text { Broadband anemonefish } \\
\text { Australian damsel } \\
\text { Maori cod/ scribbled rockc } \\
\text { Happy moment } \\
\text { Bream } \\
\text { Three bar porcupinefish }\end{array}$ & $\begin{array}{l}\text { Paraplesiops bleekeri } \\
\text { Amphiprion latezonatus } \\
\text { Pomacentrus australis } \\
\text { dEpinephelus undulatostriatus } \\
\text { Siganus nebulosus } \\
\text { Acanthopagrus australis } \\
\text { Dicotylichthys punctulatus }\end{array}$ \\
\hline Labrids & $\begin{array}{l}\text { Eastern blue groper } \\
\text { Diamond wrasse } \\
\text { Bluetail wrasse } \\
\text { Black-spotted wrasse } \\
\text { Foxfish } \\
\text { Goldspot hogfish } \\
\text { Pigfish } \\
\text { Striped pigfish } \\
\text { Venus tuskfish } \\
\text { Comb wrasse } \\
\text { Cloud wrasse } \\
\text { Cleaner wrasse } \\
\text { Crimsom banded wrasse } \\
\text { Maori wrasse } \\
\text { Gunther's wrasse } \\
\text { Luculent wrasse } \\
\text { Moon wrasse } \\
\text { Green moon wrasse }\end{array}$ & $\begin{array}{l}\text { Achoerodus viridis } \\
\text { Anampses caeruleopunctatus } \\
\text { Anampses femininus } \\
\text { Austrolabrus maculatus } \\
\text { Bodianus frenchii } \\
\text { Bodianus perditio } \\
\text { Bodianus unimaculatus } \\
\text { Bodianus izuensis } \\
\text { Choerodon venustus } \\
\text { Coris picta } \\
\text { Halichoeres nebulosus } \\
\text { Labroides dimidiatus } \\
\text { Notolabrus gymnogenis } \\
\text { Opthalmolepis lineolata } \\
\text { Pseudolabrus guentheri } \\
\text { Pseudolabrus luculentus } \\
\text { Thalassoma lunare } \\
\text { Thalassoma lutescens }\end{array}$ \\
\hline $\begin{array}{l}\text { Threatened } \\
\text { and } \\
\text { protected }\end{array}$ & $\begin{array}{l}\text { Black cod } \\
\text { Grey nurse shark } \\
\text { Blue devilfish } \\
\text { Spiny pipehorse }\end{array}$ & $\begin{array}{l}\text { Epinephelus daemelii } \\
\text { Carcharias taurus } \\
\text { Paraplesiops bleekeri } \\
\text { Solegnathus spinosissimus }\end{array}$ \\
\hline
\end{tabular}


Table S2 Summary of species distribution model statistics. Values are p-values with coefficient symbol (positive or negative), which indicates a positive or negative effect of that explanatory variable on that fish spp. / group (for depth, a negative value indicates there are more fish deeper). AUC is the predictive accuracy metric used for prevalence models. Explanatory variables are removed if not significant $(p>0.05)$, marginally significant $(\mathrm{p}=0.06-0.1)$ are shown in gray text if retained in final model. $\mathrm{N}=$ North, $\mathrm{S}$

$778=$ South .

\begin{tabular}{|c|c|c|c|c|c|c|c|}
\hline \multirow[t]{2}{*}{ Variable } & \multicolumn{2}{|c|}{$\begin{array}{c}\text { Snapper } \\
\text { Abundance }\end{array}$} & \multicolumn{2}{|c|}{$\begin{array}{l}\text { Black spotted } \\
\text { goatfish } \\
\text { Abundance }\end{array}$} & \multicolumn{2}{|c|}{$\begin{array}{l}\text { Maori wrasse } \\
\text { Abundance }\end{array}$} & \multirow{2}{*}{$\begin{array}{c}\begin{array}{c}\text { Crimson banded Wrasse } \\
\text { Abundance }\end{array} \\
\text { Both N \& S } \\
\end{array}$} \\
\hline & $\mathrm{N}$ & $\mathrm{S}$ & $\mathrm{N}$ & $\mathrm{S}$ & $\mathrm{N}$ & $\mathrm{S}$ & \\
\hline $\begin{array}{l}\text { Northing } \\
\text { Depth } \\
\text { Distance Coast } \\
\text { Zone (SZ) } \\
\text { Zone (HPZ) } \\
\text { Zone (GUZ) } \\
\text { Reef area } \\
\text { Depth SD } \\
\text { Curvature } \\
\text { Fractal dimensions } \\
\text { Site as random (SD) } \\
\end{array}$ & 0.02 & $\begin{array}{c}-0.003 \\
\\
0.03 \\
1.054 \\
\end{array}$ & $\begin{array}{c}0.009 \\
0.06 \\
-0.002 \\
-0.003\end{array}$ & -0.02 & $\begin{array}{c}-0.009 \\
-0.001 \\
-0.01\end{array}$ & $\begin{array}{l}-0.001 \\
-0.001\end{array}$ & $\begin{array}{r}0.001 \\
-0.002\end{array}$ \\
\hline $\begin{array}{l}\text { Pearson } \mathrm{D}^{2} \\
\text { AUC mean }\end{array}$ & $\begin{array}{l}10 \% \\
0.69\end{array}$ & $\begin{array}{l}34 \% \\
0.71\end{array}$ & $\begin{array}{l}34 \% \\
0.74\end{array}$ & $\begin{array}{l}26 \% \\
0.70\end{array}$ & $\begin{array}{l}74 \% \\
0.97\end{array}$ & $\begin{array}{l}63 \% \\
0.91\end{array}$ & $\begin{array}{c}48 \% \\
0.91\end{array}$ \\
\hline
\end{tabular}

779

\begin{tabular}{|c|c|c|c|c|c|c|c|c|c|c|}
\hline \multirow[t]{2}{*}{ Variable } & \multicolumn{2}{|c|}{$\begin{array}{l}\text { Blind shark } \\
\text { Prevalence }\end{array}$} & \multicolumn{2}{|c|}{$\begin{array}{l}\text { Pearl perch } \\
\text { Abundance }\end{array}$} & \multicolumn{2}{|c|}{$\begin{array}{l}\text { Venus tuskfish } \\
\text { Abundance }\end{array}$} & \multicolumn{2}{|c|}{$\begin{array}{l}\text { Tarwhine } \\
\text { Prevalence }\end{array}$} & \multicolumn{2}{|c|}{$\begin{array}{c}\text { Gray morwong } \\
\text { Prevalence }\end{array}$} \\
\hline & $\mathrm{N}$ & $\mathrm{S}$ & $\mathrm{N}$ & $\mathrm{N}$ & $\mathrm{S}$ & $\mathrm{N}$ & $\mathrm{N}$ & $\mathrm{S}$ & $\mathrm{N}$ & $\mathrm{S}$ \\
\hline $\begin{array}{l}\text { Northing } \\
\text { Depth }\end{array}$ & & 0.05 & & $\begin{array}{l}0.04 \\
-0.001\end{array}$ & -0.04 & $\begin{array}{l}-0.001 \\
-0.001\end{array}$ & 0.08 & 0.009 & -0.009 & $\begin{array}{l}0.03 \\
-0.005\end{array}$ \\
\hline Distance Coast & & & & & -0.001 & -0.009 & 0.06 & & 0.04 & \\
\hline Zone (SZ) & & 0.03 & 0.08 & & -0.03 & & & & & 0.05 \\
\hline Zone (HPZ) & & & -0.05 & & & & -0.04 & -0.005 & & \\
\hline Zone (GUZ) & -0.01 & -0.01 & & & & & & -0.07 & & \\
\hline Reef area & & & 0.04 & & & 0.005 & & -0.01 & & \\
\hline Depth SD & & & & & & & & 0.01 & 0.05 & \\
\hline Curvature & & & & & & & & & & -0.02 \\
\hline Fractal dimensions & & & & & & -0.002 & & 0.01 & & -0.02 \\
\hline $\begin{array}{l}\text { Depth* Depth SD } \\
\text { Depth*Northing }\end{array}$ & & & -0.008 & & & & & & -0.03 & -0.02 \\
\hline Pearson $\mathrm{D}^{2}$ & $25 \%$ & $30 \%$ & $39 \%$ & $13 \%$ & $55 \%$ & $52 \%$ & $21 \%$ & $49 \%$ & $40 \%$ & $48 \%$ \\
\hline AUC mean & 0.86 & 0.94 & 0.83 & 0.78 & 0.88 & 0.85 & 0.76 & 0.73 & 0.81 & 0.81 \\
\hline
\end{tabular}

780 


\begin{tabular}{|c|c|c|c|c|c|c|c|c|c|c|}
\hline \multirow[t]{2}{*}{$\begin{array}{l}\text { Variable } \\
\text { Model type }\end{array}$} & \multicolumn{2}{|c|}{$\begin{array}{c}\text { Target } \\
\text { piscivores } \\
\text { Prevalence }\end{array}$} & \multicolumn{2}{|c|}{$\begin{array}{c}\text { Target } \\
\text { predators } \\
\text { Abundance }\end{array}$} & \multicolumn{2}{|c|}{$\begin{array}{l}\text { Benthic sharks } \\
\text { Prevalence }\end{array}$} & \multicolumn{2}{|c|}{$\begin{array}{c}\text { Subtropical } \\
\text { endemics } \\
\text { Abundance }\end{array}$} & \multicolumn{2}{|c|}{$\begin{array}{c}\text { Labrids } \\
\text { Abundance }\end{array}$} \\
\hline & $\mathrm{N}$ & $\mathrm{S}$ & $\mathrm{N}$ & $S$ & $\mathrm{~N}$ & $\mathrm{~S}$ & $\mathrm{~N}$ & NA & $\mathrm{N}$ & $S$ \\
\hline $\begin{array}{l}\text { Northing } \\
\text { Depth } \\
\text { Distance Coast } \\
\text { Zone (SZ) } \\
\text { Zone (HPZ) } \\
\text { Zone (GUZ) } \\
\text { Reef area } \\
\text { Depth SD } \\
\text { Curvature } \\
\text { Fractal dimensions } \\
\text { Depth* Fractal } \\
\text { Depth* Depth SD } \\
\text { Site as random }\end{array}$ & $\begin{array}{c}-0.007 \\
-0.03 \\
-0.07 \\
0.03\end{array}$ & -0.02 & $\begin{array}{l}0.001 \\
0.001\end{array}$ & -0.05 & $\begin{array}{l}-0.01 \\
-0.01\end{array}$ & $\begin{array}{l}0.004 \\
0.001\end{array}$ & $\begin{array}{r}0.001 \\
0.06\end{array}$ & $\begin{array}{c}0.001 \\
0.001 \\
0.03\end{array}$ & $\begin{array}{c}0.003 \\
0.001 \\
0.001 \\
0.001 \\
0.001 \\
-0.06 \\
0.02 \\
\\
-0.001 \\
0.309\end{array}$ & 0.001 \\
\hline $\begin{array}{l}\text { Pearson } \mathrm{D}^{2} \\
\text { AUC mean }\end{array}$ & $\begin{array}{l}20 \% \\
0.65\end{array}$ & $\begin{array}{l}5 \% \\
0.63\end{array}$ & $\begin{array}{l}11 \% \\
\text { NA }\end{array}$ & $\begin{array}{l}25 \% \\
\text { NA }\end{array}$ & $\begin{array}{l}24 \% \\
0.78\end{array}$ & $\begin{array}{l}25 \% \\
0.80\end{array}$ & $\begin{array}{l}20 \% \\
0.73\end{array}$ & $\begin{array}{l}12 \% \\
0.66\end{array}$ & $\begin{array}{l}57 \% \\
\text { NA }\end{array}$ & $\begin{array}{c}49 \% \\
0.81\end{array}$ \\
\hline
\end{tabular}

783

784 
785 Table S3 Table comparing the area selected at least $40 \%$ of the 10,000 iteration runs by 786 the habitat classification scheme (HCS) and the species distribution models (SDM)

787 scenario. Comparison of Marxan.io scenarios using habitat classification scheme (HCS)

788 and species distribution models (SDM) as conservation targets: $80 \%$ of the area was not

789 selected by either scenario more than $40 \%$ of the 10,000 iterations, the HCS selected $18 \%$

790 of the area at least $40 \%$ of the time, while the SDM scenario selected $6.5 \%$ of the area

791 and there was an overlap of 5.8\% between scenarios. See Figure 2 in manuscript.

\begin{tabular}{lll}
\hline Class & Hectares (total 2855) & Percent \\
\hline Neither > 40\% & 2289 & $80.5 \%$ \\
only HCS > 40\% & 372 & $13 \%$ \\
only SDM_grp > 40\% & 20 & $0.7 \%$ \\
Both HCS and SDM_grp > 40\% & 165 & $5.8 \%$ \\
\hline
\end{tabular}

792

793

794 


\section{Supplementary Figures}

796 Figure S1 Figure with maps of the 28 species distribution models - see attached

797 Figure S2 Figure with frequency maps of 7 scenarios - see attached

798
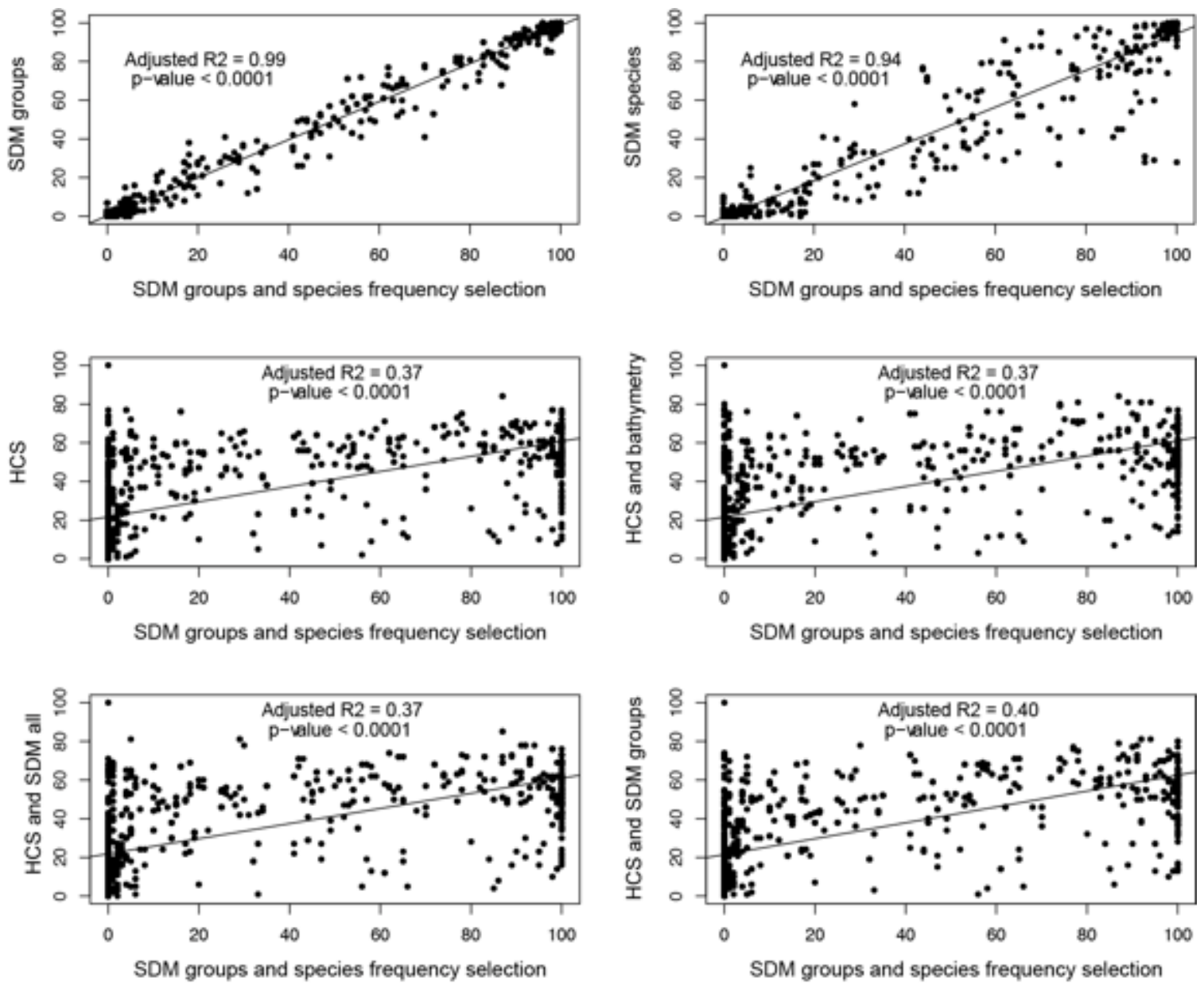

Figure S3 Relation between the SDM scenario frequency of election and the other six

801 scenarios. Note the very high correlation with the SDM groups and the SDM species, and

802 weak but significant relation to the HCS scenarios. 


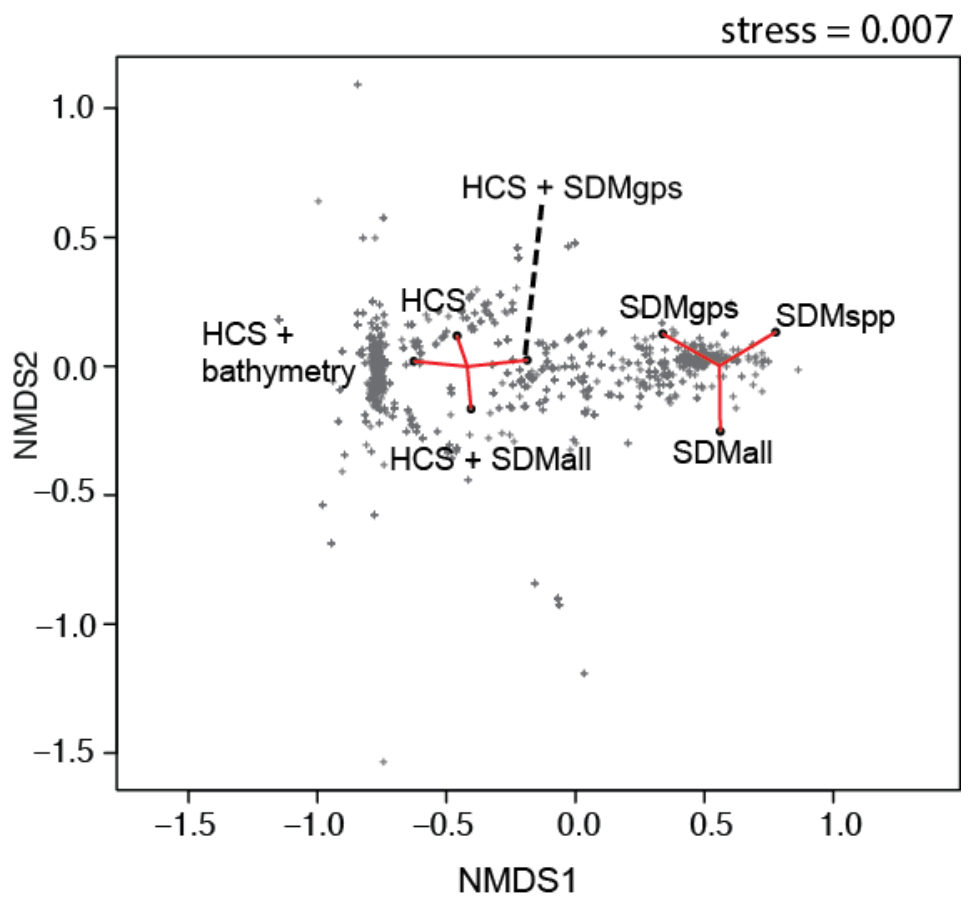

803

804 Figure S4 Non-metric multidimensional scaling plot of the distance between the 805 frequency selection for each of the seven scenarios. The two clusters are significantly 806 different.

807 